\title{
TERRORISMO Y PRINCIPIO DEMOCRÁTICO
}

ANTONIO TORRES DEL MORAL 
SUMARIO

I1. INTRODUCCIÓN. 2. VALORES Y FINES DEL ESTADO. 3. LA DIALÉCTICA SEGURIDAD-LIBERTAD. 4. INSTRUMENTOS JURÍDICOS AL SERVICIO DE LA SEGURIDAD. 4.1. Sumaria reseña histórica. 4.2. Una equivocada gestión del problema. 4.3. Retroceso de la juridicidad estatal. hacia un Derecho penal del enemigo. 5. REFERENCIA A ESPAÑA. 5.1. De los estados constitucionales críticos a la normalización de la excepción. 5.2. Dos épocas en la lucha antiterrorista española postconstitucional. 5.2.1. Primera época: coexistencia del Derecho penal del enemigo con el principio de no intervención y el hipergarantismo. 5.2.2. Segunda época: Suspensión y disolución de los partidos políticos. 6. REPERCUSIONES ELECTORALES DE LA SUSPENSIÓN Y DISOLUCIÓN DE UN PARTIDO POLÍTICO. 6.1. La proliferación de candidaturas sucedáneas y su laboriosa ilegalización. 6.2. Posible inclusión en las candidaturas de personas condenadas por delitos de terrorismo. 7. REPERCUSIONES FINANCIERAS. 7.1. Merma o pérdida de la financiación pública. 7.2. Liquidación patrimonial. 8. REPERCUSIONES POLÍTICO-INSTITUCIONALES. 8.1. Relación de algunos efectos habidos. 8.2. Conservación de los escaños. 8.3. La no disolución del grupo parlamentario. 9. ¿ES LA ESPAÑOLA UNA DEMOCRACIA MILITANTE? 10. EL ESTADO DEMOCRÁTICO, ÚNICA RESPUESTA. 10.1. Terrorismo, réplica estatal y valores. 10.2. Exigencias de los principios democrático y de juridicidad estatal. POST SCRIPTUM. 


\title{
TERRORISMO Y PRINCIPIO DEMOCRÁTICO
}

\author{
POR \\ ANTONIO TORRES DEL MORAL \\ Catedrático de Derecho Constitucional
}

\section{INTRODUCCIÓN}

Este trabajo tuvo sus inicios en la participación en diversos seminarios y cursos sobre la materia, uno solo de los cuales se ha visto traducido a letra impresa. Retomado después para un curso de verano de la UNED que dirigí en 2009, espera verse pronto encuadernado en un pequeño libro del que las presentes páginas son meramente un parcial anticipo.

Y me introduje en el presente empeño pese a la clara conciencia de que, si siempre ha sido difícil escribir sobre los valores en la acción política, hoy casi sobrepasa los límites de la prudencia. La emergencia de un terrorismo globalizado ha golpeado a las democracias de manera inmisericorde y ha motivado que la opinión pública se divida ariscamente entre quienes afirman que no puede haber libertad sin seguridad y quienes sostienen que no puede haber seguridad sin libertad, entre quienes reclaman a toda costa mano dura con la delincuencia, con toda delincuencia, pero aún más con la relacionada con ese fenómeno devastador, y quienes sostienen que la respuesta de un Estado de Derecho no puede ser cualquier respuesta, aunque ello dificulte la lucha contra esa delincuencia tan execrable.

Hace medio siglo muchos aprendimos con Manuel GARCÍA-PELAYO el concepto racional normativo de Constitución ${ }^{1}$ y también que el Estado de Derecho fue desustanciado por el positivismo jurídico. Menos compatible, por hi-

${ }^{1}$ GARCÍA-PELAYO, M.: «Derecho Constitucional Comparado», en Obras Completas (en adelante, OC), 1. ${ }^{\text {e }}$ ed., Centro de Estudios Constitucionales, Madrid, 1991, vol. I, pp. 260-265. 
perbólico, es su aserto de que el Estado de Derecho fue totalmente desnaturalizado por KELSEN sobre la base de negar su contenido axiológico ${ }^{2}$. En efecto, el jurista austriaco sostiene en Esencia y valor de la democracia ${ }^{3}$ el apoyo de ésta en la libertad y no la desliga de la igualdad, bien que secundariamente y como límite de aquélla, pudiéndose formular la conjugación de ambas como libertad igual, "consistente en una participación alícuota en la formación de la voluntad estatal». Y en su obra posterior ${ }^{4}$, sin desdecirse de la tesis expuesta, se muestra aún más receptivo de la idea de que la igualdad es esencial para la democracia: "La democracia... aspira a ser en lo posible una sociedad de colaboración entre iguales...». A mi juicio, por muy técnica y metodológicamente que entendiera la libertad, hay en la concepción citada una clara toma de posición axiológica.

Por mi parte, he defendido repetidamente el concepto prescriptivo, normativo, axiológico de la democracia, son negar el metodológico ${ }^{5}$, y desde él enfoco el objeto de la presente reflexión, que se instala en el paso, igualmente señalado por el citado maestro, del Estado legal de Derecho al Estado constitucional de Derecho ${ }^{6}$, habido en (no todos) los regímenes demoliberales.

Como nos enfrentamos a un problema sobre el que se ha dicho y escrito todo, o casi todo, creo que es recomendable comenzar por el principio, esto es, exponiendo algunas ideas veteranas, que no han perdido su vigor ni su valor teórico, tanto acerca de los fines del Estado cuanto sobre la Constitución como pacto social y político, para identificar inmediatamente tres paradigmas clásicos de la relación entre seguridad y libertad. Sólo después nos adentraremos en las respuestas de las democracias actuales, no siempre cohonestables con dichas ideas directrices, así como la posición más respetuosa con las exigencias de los principios democrático y de juridicidad estatal. Me adentraré más adelante en el problema central de este trabajo, la dialéctica entre seguridad y libertad, para aludir seguidamente a la respuesta del Estado de Derecho al terrorismo con instrumentos jurídicos democráticos.

\section{VALORES Y FINES DEL ESTADO}

Decía Max WEBER un tanto hiperbólicamente que ningún fin es ajeno al Estado, que éste, en sus variadas políticas, atiende, directa o indirectamente, a todos

2 Ibidem, pp. 356-359,

3 KELSEN, H.: Esencia y valor de la democracia, edic. de Labor, Barcelona, 1977, p. 126.

${ }^{4}$ Id.: Forma de Estado y Filosofía, en edición conjunta con la anterior, pp. 138 y 147.

5 TORRES DEL MORAL, A.: Estado de Derecho y democracia de partidos, Publicaciones de la Facultad de Derecho de la Universidad Complutense, 2. ${ }^{\text {e }}$ ed., Madrid, 2004, pp. 282-289.

${ }^{6}$ Id., «Estado legal y Estado constitucional de derecho», OC, ob. cit., vol. III, pp. 2029-2039. 
los ámbitos de la vida humana. El Estado weberiano se nos presenta, pues, como panteleológico. Y ha habido una general coincidencia en que es eso precisamente lo que justifica al Estado: los fines plurales, muy plurales, que cumple, mucho más que las organizaciones políticas antecesoras suyas, como la polis y la civitas.

Sobre los fines de la vida política ha habido una muy abundante literatura desde el principio del pensamiento político. Pluralidad de fines (sean, por ejemplo, la justicia, la paz, la libertad o la igualdad) que, sin embargo, se ha intentado, a lo largo de la historia, denominar con un único nombre comprensivo de todos ellos. A sabiendas, pues, del anacronismo en que incurro al aludir a estos fines, o a su expresión sintética, sin diferenciar entre diversas épocas ni entre distintas formas de organización política, tendríamos un cuadro aproximado al siguiente ${ }^{7}$ :

- ARISTÓTELES habló de eudsén, buena vida, vida suficiente, felicidad.

- La escolástica usó diversas expresiones más o menos sinónimas: bien común, bien general, utilidad general, interés de la república.

- Los filósofos ilustrados gustaron de hablar de progreso como comprensivo de todos los bienes.

- Los utilitaristas acuñaron la fórmula «la mayor felicidad para el mayor número posible».

- Desde hace casi un siglo se habla de bienestar social, de bienestar general.

- También, hace cuarenta años, se habló de desarrollo, en su sentido más amplio: desarrollo económico, social, cultural y político; bástenos con recordar la encíclica de PABLO VI Populorum progressio.

- Una expresión más reciente es la de calidad de la vida, en la que se incluyen todos los valores vigentes en la sociedad actual, desde la justicia social hasta el cuidado del medio ambiente, pasando por la libertad, el desarrollo, la paz, etcétera.

- Combinando las dos últimas fórmulas al gusto de nuestros días, podríamos expresar el conjunto de los fines estatales en la procura de un desarrollo sostenible.

7 Me he referido a ello en mi libro Ética y Poder, Azagador, Madrid, 1974, pp. 280-285, y posteriormente en mi intervención en la Mesa Redonda «La seguridad en España y América: expectativas y previsiones de futuro», en VV.AA.: La Guardia Civil ante su V Centenario (III Seminario «Duque de Ahumada»), Ministerio del Interior, Madrid, 1992, pp. 196-197, y «Libertades públicas y Fuerzas de Seguridad", en VV.AA.: Constitución y Seguridad Pública: una reflexión a los veinticinco años (XVI Seminario "Duque de Ahumada"), Madrid, Ministerio del Interior, 2005, pp. 25 ss. 
Cualquiera de estas fórmulas puede valer como expresión de la pluralidad teleológica del Estado social y democrático de Derecho, que ha visto aumentados sus cometidos y se ve precisado de armonizarlos. Pero, sea cual fuere la expresión utilizada, debe tenerse conciencia clara de que no se trata de un fin concreto que pueda oponerse a otros (como se suele oponer, por ejemplo, el bien común al interés particular), sino de un concepto, con el que se alude a un conjunto de derechos, bienes y condiciones de vida social que - éstos sí- permiten y favorecen a los individuos el desarrollo de sus posibilidades y el logro de una vida digna, y también a los grupos en la medida en que estos términos les sean aplicables.

Que haya personas, grupos o programas políticos que pongan el acento más en unos valores que en otros es comprensible, porque nos hallamos en el ámbito de lo opinable. Sin embargo, ello no significa que podamos reducir el problema a eslóganes: prefiero la injusticia al desorden, dijo GOETHE; prefiero las ciudades a los cementerios, se le podría replicar; libertad, sí, pero no libertinaje; orden, sí, pero no ordenancismo; autoridad, sí, autoritarismo, no... Por este camino ningún avance razonable puede esperarse, pues no es alcanzable la justicia sin un mínimo de orden y estabilidad, como tampoco viceversa; ni la libertad real puede darse donde hay demasiada desigualdad, así como tampoco la igualdad es ningún valor positivo en una situación de esclavitud.

Hay que rechazar las síntesis esquemáticas y elementales, que no responden a la complejidad de los problemas. En una sociedad hace falta un consenso básico, pero, junto a él o dentro de ese clima, existen conflictos por diferentes cuestiones sociales, económicas, culturales y políticas. Cuando lo que se demanda es seguridad, ley y orden porque están por debajo de los mínimos tolerables, se puede correr el riesgo de que los poderes públicos atiendan estos valores con cierta desatención de los demás; cuando, por el contrario, esa demanda está bien atendida, hay una cierta inclinación a juzgar excesiva la actuación de la fuerza pública, tachándola de represora, y lo que se reclama es más libertad. Cuando lo que escasea son los bienes básicos elementales (educación, alimentos, sanidad), se suele exigir igualdad en el acceso a los mismos; pero, si se subordina todo a la consecución de esos bienes con mano férrea y no se encuentra el momento de restablecer y promover otros fines, igualmente atendibles, como las libertades públicas, se está a un paso de perpetuar una dictadura totalitaria; si se me permite ejemplificarlo con un solo país, el caso de Cuba es paradigmático.

Para situarnos en la perspectiva correcta, debemos considerar:

a) que estamos ante un conjunto de valores o condiciones de vida social;

b) que su fomento y respeto responde a exigencias humanas que han ido adquiriendo perfiles sucesivos a lo largo de la Historia; 
c) que la falta total o la merma excesiva de uno de esos valores hace resentirse a los demás y, por ende, a la vida comunitaria; formulémoslo con mayor concreción: que sin libertad no hay autoridad, sino opresión; que sin seguridad personal y ciudadana no hay progreso; que la desigualdad es, como ya señaló ARISTÓTELES hace veinticuatro siglos, la causa de las revoluciones;

d) que todos esos fines políticos deben ser procurados de la manera más equilibrada y armónica posible para que el cuerpo social no quiebre; $\mathrm{o}$, dicho de otra manera, que se debe intentar realizarlos en reciprocidad continua y progresiva;

e) que, por todo ello, la idea directriz de este progreso equilibrado es la obtención del máximo de cada uno de estos valores que no obstaculice ni perjudique la consecución de otro en nada o lo haga sólo en el minimo inevitable;

f) que, en la procura de ese conjunto de condiciones de vida social, los programas políticos deben proponerse objetivos posibles, pero que la política es el arte de hacer posible lo necesario; o, lo que es igual, que los fines imposibles no son fines políticos, sino engaños, pero que, aunque algunos fines son posibles a corto plazo, hay otros que lo son a medio o a largo plazo si se acometen con continuidad y con el ritmo adecuado;

g) que, por tanto, en esa tarea política debe observarse un orden de prioridades, en su triple versión de prioridad lógica (puesto que es lógico hacer escuelas antes que universidades), axiológica (ya que es en sí misma más valiosa una política de viviendas sociales que de locales de esparcimiento) e histórica, coyuntural o de oportunidad (por ejemplo, inversión en instalaciones de ocio y de turismo como medio de obtención de los recursos necesarios para el fomento del arte y de la ciencia);

h) todo lo cual, en suma, arguye que los programas y toda la acción política debe tener como criterio de actuación la proporcionalidad entre los medios empleados y los fines perseguidos y la idoneidad de aquéllos respecto de éstos.

i) que, por eso, tales programas deben ser coherentes para ser creíbles, porque lo que en definitiva importa es ese conjunto de condiciones de vida social globalmente considerado al que llamamos bien común, calidad de vida o desarrollo sostenible. 


\section{LA DIALÉCTICA SEGURIDAD-LIBERTAD}

El anterior excursus nos aporta suficientes recursos para encarar con garantías la estéril polémica que intermitentemente se produce en nuestro país acerca de una supuesta relación de primacía entre la libertad y la seguridad, debate ante el cual es preciso perfilar debidamente nuestra posición, aunque se puede adivinar por lo antes expuesto. Aun así, todavía puede sernos de utilidad una ojeada a los clásicos del pensamiento político.

\subsection{Tres paradigmas de la relación entre seguridad y libertad}

Son de recordar, en efecto, como muy pertinentes para nuestro discurso, tres pensadores que encarnan otras tantas posiciones, interesantes y paradigmáticas, sobre la cuestión planteada: Hobbes, Locke y Condorcet. Podríamos elegir otros, pero éstos ilustran bien las tres posiciones que suelen esgrimirse al respecto. Los tres tienen puntos en común, como el pacto social inicial, pero divergen en las soluciones propuestas para los problemas que se generan -o que podemos intuir que se generarían - en el paso del estado de naturaleza a una comunidad política.

Según HOBBES, pensador inglés de la mitad del siglo XVII, la vida en estado de naturaleza era triste, insegura, miserable y breve ${ }^{8}$, porque, como impera la igualdad entre los hombres, todos pueden disputarse entre sí los recursos necesarios para su subsistencia; por tanto, todos son enemigos potenciales, e incluso reales, entre sí. El hombre, concluía con frase de Horacio que se repite incesantemente desde entonces, es un lobo para el hombre. Ante esta situación, el único remedio aceptable para la filosofía política de la época era el pacto social y político; esto es: los hombres acuerdan formar una comunidad y entrar a vivir en el estado civil, para lo cual necesitan que nadie pueda hacer violencia a nadie y que nadie se vea obligado a defenderse de nadie. HOBBES le da un sentido marcadamente autoritario al modo de evitar la miseria e inseguridad «naturales»; a saber: los sujetos pactantes ponen todo su poder en manos del soberano, que a partir de ese momento lo ejercerá de modo absoluto, inapelable e irresistible, viniendo la seguridad a ser el primer, si no el único, fin justificativo del Estado al que se subordinan todos los demás.

El polo opuesto lo encarna CONDORCET, aristócrata del siglo XVIII, ilustrado, geómetra, filósofo y masón, que, con un punto de partida semejante al

\footnotetext{
${ }^{8}$ HOBBES, T.: Leviatán, XIII, y De Cive, I, 11-14.
} 
anterior, diagnostica, por lo que se refiere a la relación entre los derechos (o la libertad) y el poder político, que los primeros son un valor absoluto e incondicionado, porque le corresponden al hombre por el hecho de serlo, y que el poder debe ser siempre limitado y condicionado. El poder se justifica por los derechos a los que sirve, y no al revés. La seguridad es uno de esos derechos, pero también la libertad, la igualdad, la propiedad, la participación, etc. Para CONDORCET, la libertad, las libertades concretas, lo son todo en una vida en común y el poder político debe limitarse a su cuidado, defensa y promoción. Pero, frente a HOB$\mathrm{BES}$, este segundo pensador no ve motivos de seguridad que justifiquen una restricción de los derechos; ni siquiera en caso de guerra ${ }^{9}$, cuanto menos en situaciones no tan graves.

El tercer filósofo al que quiero referirme, LOCKE, encarna lo que podríamos denominar tercera vía, término medio o mesotés aristotélico, si bien fue propuesta en el siglo XVII, poco después de la primera y antes de ser formulada la segunda. Con un punto de partida igual, en el que el estado de naturaleza se identifica con la inseguridad, los hombres pactan la entrega de su poder a la autoridad que constituyen en ese momento fundacional, entrando a vivir en un estado civil. Pero ¿̇no será demasiado arriesgado que esa autoridad sea tan poderosa $y$, sobre todo, tan inapelable e irresistible como propone HOBBES? Parafraseando las ideas de su conocida obra Segundo Tratado sobre el Gobierno Civil, podemos continuar la exposición de su pensamiento. Según LOCKE, un hombre sensato no suscribiría un pacto así, sino que se reservaría más poder que el que otorga; sobre todo, se reservaría el poder de cambiar al titular de la autoridad si le va mal en la puesta en práctica del proyecto. Porque esa autoridad ha sido instituida, sí, para lograr la seguridad, pero no la seguridad de la propia autoridad, sino la de los derechos naturales de los ciudadanos: su vida, su libertad y su propiedad $^{10}$.

No hay, por tanto, para LOCKE, pacto de sumisión incondicional, sino de obediencia razonable. Debemos, pues, preservarnos de esa fuerza formidable que hemos creado, no se nos vaya a ir de las manos y llegue a sojuzgarnos. Hace falta controlar el poder y exigirle responsabilidad, pues, de lo contrario, caeríamos en tiranía. Resumiendo, hace falta dotar a la autoridad de fuerza, sí, pero de una fuerza responsable; es necesaria la seguridad, sí, pero con vistas a alcanzar más li-

9 CONDORCET, J. A. C.: «Lettres d'un bourgeois de New Haven aux Messieurs du Tiers État», OC, Henrich, Fuchs, Köenig et Levrault, Schöel et Cie, Paris, 1804, XII, pp. 81-82 y 106; «Déclaration des droits», OC, ob. cit., XII, p. 257.

${ }^{10}$ LOCKE, J.: Ensayo sobre el gobierno civil, II, VII, 87, 95 y 97 y II, IX, 123, entre otros pasajes. 
bertad, no para lo contrario. El modo de conseguir todo esto, según LOCKE, es, como se sabe, la división de poderes, su recíproco control, etcétera.

Después, en los siglos posteriores, la idea de pacto siguió latente en el concepto de Constitución y en el Derecho internacional. Lo primero, como respeto a las reglas del juego adoptadas por el poder constituyente; lo segundo, como respeto a los tratados: pacta sunt servanda. Aunque el procedimiento seguido para su elaboración y aprobación parezca no hacer referencia a ello, toda Constitución digna de tal nombre, esto es, toda Constitución democrática, tiene siempre algo de pacto: pacto sobre los valores fundamentales con los que esa sociedad quiere vivir, pacto sobre las reglas del juego con las que quiere operar, pactos entre fuerzas sociales y políticas, pacto entre instituciones y, en caso de tener el Estado una estructura territorial descentralizada, pacto ¿por qué no? entre los correspondiente entes jurídico-políticos — no entre territorios, como es obvio- formalizado por sus representantes.

\subsection{La ley, punto de encuentro}

Como juristas, no podemos aceptar que se subviertan los fines del Estado y del Derecho; pero, cuando los recursos escasean, hacerse con ellos o restaurarlos se convierte en un fin coyunturalmente primario, o, al menos, no es seriamente objetable que pudiera llegar a serlo; no digo que por ser primario sea superior, pero sí funcionalmente más urgente que el fin o fines a cuyo servicio se pone - o debe ser puesto- en normalidad de circunstancias. Pero ¿̇cuándo las circunstancias políticas son normales, cuándo no están afectadas de urgencias y provisionalidades, cuándo no están condicionadas por recursos que escasean o por sucesos que no se controlan, pero que, no obstante, se debe contar con ellos, al menos hasta que podamos valernos por nosotros mismos si es que alguna vez nos vemos libres de tales ataduras?; ¿cuándo, en fin, puede un gobernante sentarse tranquilo en la mesa de su despacho y decir, o pensarlo al menos: «Bien, una vez controladas todas las variables del presente y aun del futuro, por fin voy a poder gobernar con arreglo a una razonable teoría del Estado»?

No estamos haciendo sino reiterar la tesis ya esbozada en el epígrafe anterior acerca de que los fines políticos y los valores no pueden conseguirse plenamente más que de modo armonizado, recíproco y circular (o, más deseablemente, espiral, esto es, en un sentido siempre más amplio y ascendente). De manera que ni es posible la justicia en medio del desorden, ni, malgré GOETHE, es posible el orden en un sistema que hace de la desigualdad y de la injusticia su ci- 
miento y estructura. En los pocos años que llevamos de siglo XXI lo estamos viendo constantemente.

Quiere esto decir que, en la relación entre los fines políticos éticamente asumibles (y ya sabemos que unos fines pueden ser medios para alcanzar otros), acaso los instrumentales sean en un determinado momento más urgentes porque son ineludibles para alcanzar aquellos otros que hemos dado en considerar superiores. Trayendo esta tesis a nuestro objeto de estudio y evocando de nuevo a los tres autores clásicos arriba comentados, podemos deducir provisionalmente que sólo cuando la seguridad ha sido alcanzada por medio del monopolio de la fuerza (en seguida lo adjetivaremos) en manos del Estado los ciudadanos pueden progresar y hacerlo en libertad y con una vida acorde con su dignidad, sin ver en cada conciudadano un enemigo, un lobo, ni ser él mirado de reojo por el otro. Sin la seguridad inicial, nada del resto es posible.

Salus populi suprema lex esto, decían los romanos. Pues bien, el Estado es la organización institucional de una comunidad nacional con poder soberano. En un régimen democrático este poder soberano se traduce, entre otros extremos, en el monopolio legítimo de la fuerza física. Hay que hacer mucho hincapié en el término legítimo, sin el cual toda la teoría del Estado se desvanece (quiero decir toda la teoría democrática, pues yo no voy a colocarme ni por un instante en una perspectiva diferente). Sin dicho monopolio en manos de las autoridades que ejercen el poder estatal no se puede salir del estado de naturaleza hobbesiano ni alcanzar la libertad.

Abandonemos, por tanto, los eslóganes y las hipérboles. Los eslóganes son síntesis fáciles, sí, pero muy falsas porque oscurecen multitud de matices o prescinden de ellos y, como decía Paul VALÈRY, «la verdad de las cosas está en sus matices». Hay que pararse y analizar. Comprendo que éste es un camino más penoso, pero es el único científicamente viable, jurídicamente correcto y políticamente eficaz; por eso es el único que a mí me interesa.

En cuanto a las hipérboles, creo que de los tres modelos esbozados en un epígrafe anterior, debemos prescindir del hobbesiano y del condorcetiano; aquél por excesivamente autocrático; éste por ingenuo y muy previsiblemente ineficaz a fuer de optimista y extremadamente bienintencionado. Nos quedamos, por ende, con el lockiano, más prudente, más sensato e históricamente más reconocido, aunque acaso no siempre bien practicado.

De manera que, buscando la seguridad de los derechos, los hombres pactan constituir una comunidad y colocan al frente de ella una autoridad que ejerza el poder. Está bien claro que, de los dos polos de la relación, el poder —o la autoridad- está al servicio de los derechos y no al contrario. Pero, como hemos indicado reiteradamente, no se trata sólo del goce o ejercicio de los derechos, sino 
de su seguridad, y es la autoridad la que puede proporcionarla precisamente por medio de la fuerza, fuerza que ella ejerce monopolísticamente a través de los Cuerpos de Seguridad (o de Orden Público, o como en cada país se los nombre). Esto quiere decir, de un lado, que ninguno de los dos polos de la relación es prescindible; $y$, de otro, que la seguridad, la convivencia tranquila o la tranquilidad de personas y bienes (que de todas estas maneras ha sido llamada) se erige en conditio sine qua non del ejercicio y disfrute de los derechos. Porque no hace falta insistir más acerca de que en el caos no hay ni libertad, ni igualdad, ni derechos, ni garantías; esto último, garantías, menos aún.

¿Significa eso que la seguridad sea el elemento determinante de la relación de valores que estamos analizando? En absoluto. Debemos distinguir - y algo hemos dicho ya sobre ello- entre fines válidos en sí mismos y fines instrumentales. No vamos a solventar aquí la cuestión de si la igualdad, la justicia, el pluralismo, etc., son valores válidos en sí mismos, ni si son valores todos ellos; remito a otras páginas mías en las que me pronuncio sobre la cuestión ${ }^{11}$. Pero, por lo que aquí nos interesa, sí quiero enfatizar que la libertad es un fin válido en sí misma y por sí misma; es el valor óntica y gnoseológicamente anterior a los demás y fuente de todos ellos, incluida la dignidad, que, en un análisis filosófico y antropológico, no aparece sino como consecuencia suya.

Ahora bien, la pregunta «libertad ¿para qué?» que Lenin hizo al ilustre socialista español Julián Besteiro en la visita que éste le rindió, es sumamente inteligente. Porque aunque la libertad sea un fin válido en sí mismo, no es el único, y ha de entrar en relación con otros fines; y, si se la utiliza para establecer un orden insoportablemente injusto, termina negándose a sí misma, porque en la injusticia tampoco hay libertad, al menos a largo plazo. La justicia es también un fin político de primerísimo orden y no debemos contraponerla a la libertad, ni a la dignidad humana, sino cohonestarla con ellas armónicamente, de tal manera que puedan afirmarse y disfrutarse todas en proporciones aceptables, por debajo de las cuales la vida no merece ser vivida.

Por eso mismo podemos preguntarnos a la contra: seguridad ¿para qué? Porque lo primero que hay que decir es que la seguridad no es un fin en sí misma, sino un instrumento o, si se quiere, un fin instrumental que está al servicio de esos otros fines de los cuales hemos hablado. La seguridad no puede siquiera ser pronunciada sin referencia a las personas o a otros bienes y valores: seguridad de los derechos, seguridad de las libertades, seguridad de las instituciones. Decir se-

11 Cfr. TORRES DEL MORAL, A.: Principios de Derecho Constitucional Español, Publicaciones de la Facultad de Derecho de la Universidad Complutense, 5. a ed., Madrid, 2004, vol. I, pp. 51-60. 
guridad a secas o buscar la seguridad por la seguridad es política y éticamente rechazable. La seguridad y el orden se justifican por el clima social que prestan para el ejercicio de los derechos, no por el gusto dudosamente estético de que cada cosa esté en su sitio. La seguridad y el orden proporcionados por la ley (se entiende que democráticamente elaborada, aprobada y ejecutada, pues, insisto, en este estudio nos movemos exclusivamente en clave democrática) están al servicio de la libertad, de la justicia y de la dignidad humana, y no al revés. Sin embargo, aunque la tesis anterior parece —o así me lo parece a mí- punto menos que irrefutable, el problema no termina aquí, sino que comienza.

Tesis nada novedosa, por cierto. Ya CICERÓN defendió que sólo siendo esclavos de la ley podemos ser libres ${ }^{12}$. LOCKE cifraba la existencia de la sociedad civil (o comunidad política), frente al estado de naturaleza, en la existencia de leyes conocidas, jueces ciertos y poder suficiente para respaldar y sostener las sentencias y darles ejecución ${ }^{13}$; apenas se puede subrayar más concisa y certeramente el valor de la seguridad (no sólo jurídica) en una sociedad políticamente constituida. MONTESQUIEU, en la misma línea y más reiteradamente, concibe la libertad, de una parte, como poder hacer lo que la ley permite y no estar obligado a hacer lo que prohíbe ${ }^{14}, y$, de otra, estrechamente emparentada con la anterior, aunque a primera vista parezca escrita en clave diferente, como «la tranquilidad de espíritu que proviene de la opinión que cada uno tiene de su seguridad $\rangle^{15}$; o bien sostiene, hablando en términos tanto individuales como colectivos, que «la única ventaja de un pueblo libre sobre otro reside en la seguridad de cada cual de que el capricho de cualquiera no le arrebatará ni sus bienes ni su vida» ${ }^{16}$; o, en fin, refiriéndose a la sociedad entera: «un pueblo libre no es el que tiene tal o cual forma de gobierno, sino el que goza de la forma de gobierno establecida por la leys ${ }^{17}$; conceptos todos ellos en los que se dan cita la seguridad jurídica y la seguridad personal, que, contemplada en términos sociológicos amplios, es la ahora denominada seguridad ciudadana, y todo ello con la ley como único instrumento de gobierno válido por sí mismo.

Dicho con breves palabras, la tesis descrita podría ser formulada así: es la ley — se entiende que en sentido amplio, como Ordenamiento jurídico, y también como ley democrática en los términos arriba expuestos_la que define el orden

12 CICERÓN: Pro Cluentio, 53, 146.

13 LOCKE, J.: Ensayo sobre el gobierno civil, II, IX., 124-126.

${ }_{14}$ MONTESQUIEU: El espiritu de las leyes, XI, 3 y 4.

15 Ibidem, XI, 6.

16 Id., Mes Pensées, 1802.

17 Ibidem, 631. 
y solamente dentro de ese orden legal podemos encontrar nuestra libertad y ejercerla con seguridad.

Estamos, pues, ante la complementariedad de los valores, concepción que, entre los filósofos contemporáneos, sostiene, entre otros, J. RAWLS arguyendo que la libertad plena es la libertad segura, lo que únicamente se alcanza con leyes seguras $^{18}$. Y no anda lejos de esta idea la Constitución española cuando incluye en su artículo 9.3 los principios de la seguridad jurídica como propios del Estado de Derecho y erige, en el artículo siguiente, el respeto de la ley como fundamento del orden político y de la paz social en el mismo nivel que la dignidad humana y los derechos que le son inherentes.

Para comprender mejor la relación que estamos tratando entre estos valores, creo que es funcional acudir a unos ejemplos.

Pensemos en dos sociedades, una en la que reina el más absoluto caos y otra en la que se ha conseguido la más exquisita justicia. Se me dirá que no son más que hipótesis para montar sobre ellas una tesis, que son meros modelos teóricos para ejercer la vía de la deducción. No es cierto. Sociedades caóticas han existido y existen: en Irak, durante varios años, ha reinado, junto a una guerra injusta e ilegal, el pillaje, el saqueo, la muerte de cientos de miles de personas (militares y civiles) y el desplazamiento de millones (todos civiles); también las podemos ver cuando los ranchitos buscan su supervivencia bajando a Caracas y haciéndola temblar, o cuando los argentinos asaltan supermercados para robar comida o lo que pueda tener cierto valor en un mercado también caótico.

En estas ocasiones, que son reales, en estas sociedades que atraviesan, aunque sea pasajeramente, tales momentos, podríamos utilizar términos parecidos a los que empleó HOBBES para describir la vida en el estado de naturaleza: una vida triste, insegura, miserable y breve. En sociedades y en momentos como los descritos (que son en realidad sociedades y momentos en los que se vuelve al estado de naturaleza, a una situación —si se me permite hablar así- de preconstitucionalidad, y de lo que están necesitadas es de un pacto social y político), el orden y la seguridad se erigen en el primer bien deseado, en condición sin la que no es posible pensar siquiera en la consecución de otros valores.

En cambio, la sociedad en la que ya se ha conseguido la justicia perfecta y en la que cada cual tiene lo suyo, ni ha existido ni parece que lleguemos a verla en un horizonte temporal sensato. Esta sociedad de justicia consumada sí es un modelo meramente teórico sobre el que tanto se ha escrito, desde los utopistas (TOMÁS MORO, CAMPANELLA, etc.) hasta MARX, al que una y otra vez ente-

${ }^{18}$ RAWLS, J.: Teoría de la justicia, 2. a ed. cast., Fondo de Cultura Económica, Madrid, 1995, pp. 201 ss. 
rramos y otras tantas renace a fin de apuntarnos algo interesante para nuestros análisis. Pero dejemos a un lado la septuagésima muerte y resurrección de MARX y sigamos. En esa sociedad perfectamente justa no sería necesario velar por la seguridad ni por el orden al no haber desórdenes ni inseguridad ya que, como resulta meridiano en el modelo roussauniano, todos tienen lo que necesitan y nadie es tan rico y poderoso que pueda comprar a otro, ni nadie es tan pobre y débil que se vea obligado a venderse. En tal sociedad ninguno tiene interés en que se modifique algo para los demás en provecho propio, ya que, por hipótesis, quedaría modificado también para él mismo y en provecho de los demás ${ }^{19}$, lo que hace inviable esa alteración del pacto igualitario. En esa sociedad igualitaria restallarían espléndidamente los valores superiores del hombre, principalmente su libertad y su dignidad. La única dificultad estriba en que esa sociedad no existe ni parece que vaya a existir, lo que significa un no pequeño problema para teorizar sobre ella. Pero nadie dijo que este análisis fuera fácil.

Por eso, por seguir poniendo ejemplos concretos, el orden y la seguridad son prioritarios en Irak, en Sudán, en Afganistán, en el Perú azotado por «Sendero Luminoso"... Pero la libertad lo es en Cuba y en muchas otras dictaduras totalitarias. Y el remedio contra «Sendero Luminoso» no era, no podía ser, el terrorismo de Estado desencadenado por el Gobierno de Fujimori, que creó aún más inseguridad que la que decía combatir. En todos esos escenarios son necesarios tanto unos valores como otros: en la base, el orden y la seguridad ciudadana; proyectada al futuro, pero no desplazada indefinidamente hacia él, la libertad, para alcanzar el ejercicio de la soberanía por parte de su titular, el pueblo; para el disfrute y el ejercicio de los derechos civiles, políticos, sociales, culturales y económicos por parte de las personas, que de esta manera abandonan la condición de súbditos y se elevan a la de ciudadanos, cada uno con su parte alícuota de soberanía y de corresponsabilidad en esa suerte de empresa solidaria que es una nación; para la explotación justa de los recursos naturales y para el reparto equitativo de lo que ello produzca.

No obstante, es evidente, y así lo hemos reiterado, que las circunstancias históricas concretas confieren prioridad a unos fines sobre otros. Corresponde entonces a la prudencia política decidir acerca de dosis, de proporciones y de ritmos, pero teniendo siempre presente que no es la libertad la que está al servicio del orden, sino el orden al servicio de la libertad, como corresponde a la relación que debe existir entre valores instrumentales y valores superiores. Es fundamental no olvidarlo: el orden sirve instrumentalmente para conseguir la libertad y el disfrute de ésta y de los derechos, pero la libertad y los derechos son, axio-

19 ROUSSEAU, J. J.: Contrato social, I, 6. 
lógica y teleológicamente, fundamento y esencia de ese mismo orden, porque, como decía ARISTÓTELES, el fin, la causa final, forma parte de la esencia de las cosas.

Consiguientemente, en épocas, como la presente, en las que la seguridad es precaria en todo el mundo (o en las que esta precariedad es sentida como tal por la sociedad), la seguridad se erige en protagonista de programas gubernamentales y de campañas electorales. Pero inmediatamente debe ponerse el acento en los valores superiores; para cuando pueda ser, pero ni un minuto más tarde; tampoco con precipitación, sino con prudencia, para evitar que el pueblo sea presa de élites ilegítimas, de fundamentalistas, de populistas demagogos y de fanáticos (o no tan fanáticos ellos, pero que consiguen fanatizar a los ciudadanos). Es relativamente fácil el engaño en este terreno y justificar la perpetuación de regímenes y de situaciones de excepción, con la correspondiente merma de derechos y de libertad, esgrimiendo la excusa de la necesaria defensa de la seguridad frente a enemigos que los ciudadanos y los expertos no siempre consiguen ver.

Las conclusiones de este epígrafe se derivan derechamente de cuanto antecede: a) en primer lugar, el orden y la seguridad son el instrumento con el que trabajan los poderes públicos para conseguir cotas más altas de libertad y de una vida humana más digna; b) pero, en segundo término, el orden y la seguridad únicamente son válidos cuando se dan no sólo en los cementerios y en los hogares durante el descanso nocturno, sino también y principalmente cuando se hacen presentes en las ciudades y de día, en pleno trabajo y producción; no en una sociedad plana y aproblemática, sino en una plural, con consensos y con conflictos. No hay, pues, libertad ni justicia sin orden ni seguridad, pero el orden y la seguridad no son suficientes por sí solos para hacer sociedades dinámicas integradas por personas activas y dirigidas por una autoridad que no oculte ni provoque los conflictos a su conveniencia, sino que trabaje para atajarlos y resolverlos teniendo siempre en el horizonte, como metas, los verdaderos valores de toda vida humana digna.

\section{INSTRUMENTOS JURÍDICOS AL SERVIVIO DE LA SEGURIDAD}

\subsection{Sumaria reseña histórica}

Es de fácil memoria la clásica Declaración de Derechos del Hombre y del Ciudadano, de 1789, la cual, tras proclamar en su artículo segundo la seguridad como uno de los derechos básicos, atribuía en el decimosegundo a la Fuerza Pública la garantía de los derechos. Dicen así: 
"Art. 2. ${ }^{\circ}$ La finalidad de toda sociedad política es la conservación de los derechos naturales e imprescriptibles del hombre. Estos derechos son la libertad, la propiedad, la seguridad y la resistencia a la opresión».

«Art. 12. La garantía de los derechos del Hombre y del Ciudadano necesita de una fuerza pública; esta fuerza está, pues, instituida en beneficio de todos y no para utilidad particular de aquellos a quienes se les confiere».

Retengamos la mención que hace el primer precepto transcrito a la resistencia a la opresión, porque es otro de los elementos presentes en el pacto lockiano, conforme al cual —recordémoslo- el pacto social verdaderamente sensato consiste en crear un poder formidable para que garantice la seguridad, pero también adoptar cautelas a fin de que no se convierta él mismo en un peligro aún mayor para la libertad. Recordemos que el Preámbulo de este texto sagrado del constitucionalismo que es la Declaración de 1789 justifica la necesidad de hacerla en que la ignorancia, el olvido y el desprecio de los derechos del hombre son la causa de los males públicos y de la corrupción de los gobiernos. Dicho de otro modo: al poder político se le encarga que vele por la seguridad reprimiendo todo ataque ilegítimo a los derechos del hombre, pero hay que controlarlo e incluso oponerse a él, resistirlo, si es el poder establecido el que vulnera los derechos que tiene que preservar. Volveremos sobre ello.

Lo que sucedió durante la centuria siguiente, salvo acaso en el Reino Unido, fue una muy otra cosa: la acción policial fue utilizada no en garantía de los derechos y libertades, sino como límites suyos, cuando no en beneficio de los titulares del poder y en contra de los adversarios políticos. Teniendo en cuenta esta desviada práctica policial, puede asegurarse con F. FERNÁNDEZ SEGADO que la Europa continetal fue muy poco liberal en el siglo XIX (al menos, a este respecto, añado yo), al contrario que Inglaterra ${ }^{20}$.

A fines del siglo XIX prevaleció — dice el autor citado- una concepción instrumental de la Policía, cuyo rasgo característico no fue tanto el objetivo que tenía atribuido, cuanto su forma de actuar, es decir, la restricción de la libertad de los individuos a base de coacción ${ }^{21}$. Y no puede decirse que la situación cambiara sustancialmente durante la primera mitad del siglo XX.

Por el contrario, recién terminada la Segunda Guerra Mundial y en plena fiebre de juridicidad estatal e internacional, el Estado democrático posbélico redujo el ámbito de actuación policial reconduciéndolo y subordinándolo a la re-

20 FERNÁNDEZ SEGADO, F.: «Las Fuerzas y Cuerpos de Seguridad», en VV.AA.: Comentarios a las Leyes Politicas. Constitución española de 1978, Cortes Generales/EDERSA, tomo VIII, Madrid, 1998, pp. 433 y 435.

${ }^{21}$ Ibidem, mismo lugar. 
gulación constitucional de los derechos y libertades, para cuya garantía existe precisamente la Policía ${ }^{22}$. Aun así y como era inevitable en la cultura jurídica y política reinante, pero con mucho menor énfasis, se siguen recogiendo en los textos constitucionales las clásicas previsiones de situaciones políticamente anómalas o críticas. También los textos supranacionales e internacionales ponen su acento en la parte positiva de esta tensión dialéctica, aunque haciéndose eco igualmente, bien que como mera excepción, de la existencia de tales circunstancias a fin de autorizar a los Estados Partes a adoptar las medidas adecuadas para hacerles frente. Así, el Convenio Europeo de Derechos Humanos, de 1950, establece:

"Art. 15. Derogación en caso de estado de urgencia. 1. En caso de guerra o de otro peligro público que amenace la vida de la nación, cualquier Alta Parte Contratante podrá tomar medidas que deroguen las obligaciones previstas en el presente Convenio en la medida estricta de lo que exija la situación, y supuesto que tales medidas no estén en contradicción con las otras obligaciones que dimanan del Derecho internacional».

Reparemos, con todo, en el tono cauteloso y prudente de la redacción del precepto, que marca límites y fines a la adopción de tales medidas, como corresponde a su excepcionalidad. Además, los apartados siguientes exceptúan de esas disposiciones ciertos derechos y obligan a los Estados que las adoptaren a informar de ello, así como de su terminación, a los demás Estados Partes.

En sentido similar, y a veces con coincidencia literal, se pronuncia el Pacto Internacional de Derechos Civiles y Políticos, de 1966:

«Art. 4. ${ }^{\circ}$. En situaciones excepcionales que pongan en peligro la vida de la nación y cuya existencia haya sido proclamada oficialmente, los Estados partes en el presente Pacto podrán adoptar disposiciones que, en la medida estrictamente limitada a las exigencias de la situación, suspendan las obligaciones contraídas en virtud de este Pacto, siempre que tales disposiciones no sean incompatibles con las demás obligaciones que les impone el Derecho Internacional y no entrañen discriminación alguna fundada únicamente en motivos de raza, color, sexo, idioma, religión u origen social».

Los dos apartados siguientes del texto transcrito hacen igual salvedad e imponen la misma obligación que hemos visto en el Convenio Europeo. Vale entonces dar por reproducido el comentario anterior. En realidad, estos preceptos no hacían otra cosa que conferir rango supranacional e internacional a la previsión de estados excepcionales o críticos que se podían encontrar en la generalidad

${ }^{22}$ Cfr. ibidem, pp. 433 y 435. 
de las Constituciones antes de los referidos Pactos, como igualmente se siguen encontrando después.

\subsection{Una equivocada gestión del problema}

En correspondencia con lo apuntado hasta aquí y debido a la intensificación y a la globalización del terrorismo, del que los atentados contra las Torres Gemelas de Nueva Cork (2001) y los perpetrados en Londres (2003) y en Madrid (2004) son sus exponentes más sonados, en las dos últimas décadas del siglo XX y en lo que va del XXI se ha desatado una creciente dinámica (un sindrome, valdría decir) de valoración prioritaria de la seguridad y, en consecuencia, de una acumulación de instrumentos de procura de la misma (a cuyo servicio se pone todo el aparato estatal y especialmente la Fuerza Pública) en frecuente detrimento de las garantías constitucionales que identifican el régimen constitucional democrático.

En tal clima es frecuente plantear el enfrentamiento con el terrorismo en términos bélicos. "Guerra al terrorismo» es una exclamación que goza de claro favor popular, y buscando ese favor, que se suele traducir en votos en la decisiva hora electoral, se mueven los Gobiernos y las Oposiciones. Sin embargo, como observa D. SANSÓ-RUBERT, la «militarización» de esta lucha alimenta la estrategia terrorista, uno de cuyos escenarios preferidos pasa por conseguir donde actúa un estado de opresión tan insoportable de la población que ésta acabe reaccionando contra sus propios Gobiernos ${ }^{23}$.

En el límite, el grupo terrorista desearía sobre todo que la opinión y las instancias internacionales calificaran como bélico el conflicto generado por él; inmediatamente solicitaría el estatuto de ejército en guerra, la aplicación del Derecho internacional de guerra y la intervención de dichas instituciones como observadores neutrales de la misma. No otra cosa pretendieron durante años ETA e IRA (salvadas todas las distancias y diferencias entre estas dos organizaciones, que no son del caso explicitar aquí) y lo consiguieron parcialmente de varios Gobiernos, incluso de países socios de España y del Reino Unido.

EE.UU. no ha sabido cómo debía luchar contra el terrorismo desde el trágico atentado de la Torres Gemelas del 11 de septiembre de 2001, porque, en

23 SANSÓ-RUBERT PASCUAL, D.: «Seguridad vs. libertad: el papel de los servicios de Inteligencia», Cuadernos de la Cátedra de Fadrique Furió Ceriol, n.o 48, Universidad de Valencia, 2004, p. 97. 
realidad, nunca lo tuvo, en términos estimables, dentro de su territorio. De ahí los continuos yerros de la Administración del segundo Bush en este terreno. Su intervención en Irak es otro buen ejemplo: la primera regla que dicta el Estado de Derecho y la prudencia política es no llevar la guerra adonde no la hay, y no aumentar el caos con la inoperancia, con la negligencia o con la condescendencia, cuando no con el torpe intento de justificación del atropello de los derechos. A todo lo cual antecede la invención de la causa belli, a saber, que en Irak había una situación inicial de terrorismo, conexiones con $\mathrm{Al}$ Qaeda y armas de destrucción masiva, todo lo cual era claramente erróneo o, acaso peor aún, interesadamente falso; como se ha demostrado más tarde, el principal objetivo de la intervención militar era asegurar e incluso abaratar el suministro de petróleo, objetivo que, por lo demás, distó mucho de ser alcanzado: Irak produjo menos petróleo y su coste casi se duplicó, contribuyendo, como un factor más (si bien acaso no el más determinante) a la crisis económica mundial

No se puede hacer como el ejército invasor y ocupante de dicho país, que lo dejó caer en el pillaje, en el saqueo, en la total inseguridad y con una apariencia de poder civil carente de autoridad. Si se ha destruido un territorio buscando instaurar un orden, no se puede permanecer impasible ante el nuevo desorden. Igualmente repudiable fue la aparente asepsia del Gobierno inglés diciendo que las fuerzas que envió a Irak lo fueron para ganar una guerra, no para administrar un territorio, e insistiendo en que dichas fuerzas eran profesionales de la guerra y no de la ayuda humanitaria. En fin, redondea el despropósito el hecho evidente de que dichas actuaciones resultaron a la postre absolutamente ineficaces.

A mi juicio, las potencias invasoras estaban obligadas a proteger la población, los hospitales y las escuelas, al menos con la misma diligencia con la que han protegido los pozos de petróleo. Y se hace difícil homologar como ayuda humanitaria las destrucciones de la Biblioteca Nacional y del Museo Arqueológico Nacional; o la rapiña y la destrucción de piezas históricas y artísticas que forman parte del patrimonio de la humanidad.

En cuanto a la participación de España, o de su Gobierno, en tal desatino contraviniendo conscientemente la política internacional española de dos siglos, la legalidad internacional y la ética menos exigente, más vale no hablar. Sobre todo porque nuestro país tiene mucha experiencia y conocimiento en la lucha contra el terrorismo y sabía muy fehaciente y dolorosamente que no era ése el mejor camino para combatirlo. Afortunadamente la rectificación llegó rápida. 


\subsection{Retroceso de la juridicidad estatal. Hacia un "Derecho penal del enemigo»" ${ }^{24}$}

Como dice J. TERRADILLOS, «el terrorismo no es un fenómeno coyuntural, sino una forma de criminalidad incardinada en la cotidianidad y concebida por el poder como un elemento patológicamente estructural, al que no conviene hacer frente con instrumentos transitorios» ${ }^{25}$. En esta línea, F. MUÑOZ CONDE afirma que el terrorismo es una forma más de criminalidad organizada, aunque con una finalidad política (o... de alterar la paz pública) que la hace más peligrosa y difícil de controlar penalmente», puesto que cuenta con una gran cantidad de medios financieros nacionales e internacionales ${ }^{26}$. Esto hace que «el Derecho, concretamente el Derecho penal y el Derecho procesal penal se tengan que enfrentar con situaciones en las que los principios generales no encuentran una clara y eficaz aplicación, lo cual produce constantemente un reto para el Derecho: conseguir un punto de equilibrio entre el respeto a los principios sobre los que se construye el Estado de Derecho y una eficaz respuesta a este fenómeno» ${ }^{27}$.

Ante esta tesitura las democracias han ido adoptando legislaciones antiterroristas caracterizadas por una mayor dureza con el crimen organizado y el terrorismo, pero también, y esto es digno de ser remarcado, con la delincuencia en general. Con la peculiaridad de que todo ello se hace orillando las formalidades de la declaración del estado de excepción, operación ésta que se quiere evitar por el desgaste político que comporta o pudiera comportar para los Gobiernos ante la opinión pública nacional e internacional. Ha nacido así el denominado Derecho penal del enemigo, inserto en los códigos penales y procesales y en el resto de la legislación ordinaria, el cual aparece informado por tres elementos básicos:

- adelantamiento de la punibilidad,

- incremento desproporcionado de las penas y

- disminución de las garantías procesales.

Por más que contemos con precedentes en los años noventa de la pasada centuria, su principal mentor actual es G. JAKOBS, que parte de la necesidad de

${ }^{24}$ Cfr. DE VERGOTTINI, G.: «La difícil convivencia entre libertad y seguridad. Respuesta de las democracias al terrorismo", Revista de Derecho Político (en adelante, RDP), n. ${ }^{\circ} 61$, UNED, Madrid, 2004, pp. 11 ss.

25 TERRADILLOS BASOCO, J.: Terrorismo y Derecho, Madrid, 1988.

${ }^{26}$ MUÑOZ CONDE, F.: Derecho Penal. Parte Especial, 15. a ed., Tirant lo Blanch, Valencia, 2004, p. 903.

27 Ibidem, mismo lugar.

(C) UNED. Revista de Derecho Politico

N. ${ }^{\circ} 78$, mayo-diciembre 2010, págs. 95-160 
crear dos especies dentro de la legislación penal: una aplicable a los ciudadanos y otra a los «enemigos», entendiendo por tales aquellos que, de una manera presuntamente duradera, han abandonado el Derecho y, por tanto, no ofrecen una mínima seguridad en su comportamiento ${ }^{28}$. Como dice J. M. SILVA SÁN$\mathrm{CHEZ}^{29}$, este tipo de Derecho penal se aparta de los fines ordinarios del Derecho penal clásico y de su función rehabilitadota y de reinserción social; es más una legislación belicosa que busca la exclusión y supresión de aquellas personas que, por sus conductas, por su forma de vida o por su pertenencia a una organización delictiva, renuncian definitivamente (o así se entiende que hacen) a vivir dentro del Ordenamiento jurídico, actitud a la que éste adjudica velis nolis la consecuencia jurídica de la renuncia, al menos implícita, a los beneficios que pudieran alcanzarle. De otro lado, según M. CANCIO MELIÁ, el Derecho penal de autor vulnera el principio del hecho, genuino del Derecho penal liberal, según el cual debe excluirse la responsabilidad penal por lo que pudiéramos entender que es la actitud interna del autor ${ }^{30}$.

Consiguientemente, por este camino se ha procedido a una normalización de la emergencia, valga el oxímoron. La legislación ad hoc prescinde de dos notas siempre entendidas por la doctrina como inseparables del Derecho, cuanto más del Derecho punitivo y procesal: la permanencia y la generalidad; pues ahora se dictan leyes con término de vigencia para emergencias puntuales y también otras con destinatarios concretos. Paralelamente crece con rapidez la consideración del terrorismo como delito internacional ${ }^{31}$.

Claro que también en este terreno son perceptibles algunas diferencias: las legislaciones antiterroristas de las democracias europeas no son tan extremosas como la estadounidense ${ }^{32}$. Un breve repaso, sin ánimo de exhaustividad, nos pone de manifiesto sus principales hitos:

28 JAKOBS, G.: «La ciencia penal ante los retos del futuro», versión española de Teresa MANSO, en ESSER/BURKHARDT: La ciencia del Derecho Penal ante el cambio de milenio, coord. de la edic. española: MUÑOZ CONDE, F. (Valencia, 2004), pp. 53 ss. Cfr. igualmente JAKOBS, G., y CANCIO MELIÁ, M.: Derecho penal del enemigo, 2. a ed., Thomson-Civitas, Madrid, 2006.

29 SILVA SÁNCHEZ, J. M.: La expansión del Derecho penal, 2. a ed., Civitas, Madrid, 2001, pp. 164 ss.

${ }^{30}$ CANCIO MELIÁ, M.: Derecho penal del enemigo (en coautoría con G. JAKOBS), ob. cit., pp. 137 ss.

${ }^{31}$ Cfr. GELLI, M. ${ }^{\text {a A.: }}$ «El terrorismo y el desarrollo progresivo de un delito internacional», RDP, n. ${ }^{\circ}$ 70, UNED, Madrid, 2007.

32 Cfr. ÁLVAREZ CONDE, E., y GONZÁLEZ, H.: «Legislación antiterrorista comparada después de los atentados del 11 de septiembre y su incidencia en el ejercicio de los derechos fundamentales», Análisis del Real Instituto Elcano (ARI), n.o 8, Madrid, 2006; TENORIO SÁN- 
a) En EE.UU., tras los atentados de 2001, las famosas Patriot Act Iy II, de 2001 y 2003 respectivamente, auspiciadas por la Administración de G. Bush jr., junto con varios reglamentos y órdenes presidenciales, resultaron claramente excesivas. Su nombre oficial ya es indicativo de su propósito, aunque no de los excesos de su contenido. Patriot es acrónimo de Providing Apropriate Tools Required to Intercept and Obstruct Terrorism, o, lo que es igual, se trata de una ley que tiene como finalidad proporcionar al Estado las herramientas adecuadas para interceptar y obstaculizar el terrorismo. Pues bien, antes y después de tal legislación:

- se han conculcado sistemáticamente los derechos humanos en Abu Ghraib;

- se recluyó en Guantánamo a 600 prisioneros por tiempo indefinido como sospechosos de actividad terrorista, a los que se les limitaron los derechos frente a la detención y las garantías más elementales de defensa; todo ello sin acusación concreta, sin asistencia letrada, sin acceso a los tribunales durante tiempo interminable; en una palabra, casi reduciéndolos a la condición jurídica de cosas;

- algunas de esas cosas aparecieron muertas en extrañas circunstancias, siendo los casos calificados oficialmente de suicidios, pero con el agravante de que algún forense, al analizar varios cadáveres, denunció la falta de algunos órganos en ellos;

- se instalaron cárceles de la CIA en el extranjero, en lo que los Gobiernos europeos han tenido su alta cuota de responsabilidad, puesto que también se hizo en su territorio y con su aquiescencia o disimulo;

- se ampliaron los poderes de investigación policial y de acceso a datos personales, frecuentemente hasta límites inaceptables en un régimen democrático;

- se vetó, por parte del Presidente, una ley del Congreso que prohibía los actos de tortura y se intentó reiteradamente y se obtuvo en algunas ocasiones la validación judicial de prácticas de tortura;

- particularmente execrable es el método conocido como waterboarding, ya utilizado en tiempos no tan lejanos por los «Jemeres Rojos»,

CHEZ, P.: Constitución, derechos fundamentales y seguridad. Panorama comparativo, Entwicklungen im Europäischen Recht., Band 37, ed. Rainer Arnold, Jean-Monnet-Lehrstuhl für Europarecht, Universität Regensburg, 2007, pp. 13 ss., edic. cast., Civitas, Madrid, 2010, en prensa; del mismo autor, "Constitución y legislación antiterrorista", RDP, n. ${ }^{\circ}$ 71-72, UNED, Madrid, 2008, pp. 512517; SANSÓ-RUBERT PASCUAL, D.: «Seguridad vs. libertad: el papel de los servicios de Inteligencia», ob. cit., pp. 100 ss. 
ahora empleado contra presuntos miembros del «Al Qaeda», método que las autoridades estadounidenses se han resistido mucho a suprimir pese a la casi unánime opinión pública desfavorable;

- estas prácticas fueron juzgadas por la Administración Bush como un mal menor con el doble argumento de que son legales, seguras y necesarias y con ellas se puede obtener información con la que salvar vidas humanas, negándose a dar cuenta de ellas por la sencilla razón de que carece de sentido informar al enemigo de lo que se está haciendo.

b) En el Reino Unido se aprobó la Terrorism Act 2000y, tras los atentados de las Torres Gemelas, la Antiterrorism, Crime and Security Act 2001, que permitía derogar el artículo 5. ${ }^{\circ}$ del Convenio Europeo de Derechos Humanos en tiempo de guerra o de emergencia política y limitaba los derechos de los extranjeros y de sus abogados al tiempo que incrementaba las facultades policiales de investigación de bancos y de sociedades financieras. En lo concerniente a extranjeros, fue declarada ilegal por la Cámara de los Lores en 2004 como contraria al Convenio Europeo por no ser conforme con los principios de proporcionalidad y no discriminación.

c) En Francia, la Ley Antiterrorista de 2005 significó un aumento del control de las comunicaciones privadas, de las facultades policiales sin mandato judicial y de las penas y medidas preventivas por motivo de terrorismo.

d) En Italia se modificó la legislación penal y procesal en 2001 para introducir nuevas figuras delictivas y otras disposiciones ad hoc, pero asegurando el control judicial. Y en 2003 se ratificó la Convención Internacional para la represión de los atentados terroristas que utilizan explosivos, adoptada por la Asamblea de las Naciones Unidas en 1997.

e) En Alemania se aprobó en 2002 un «Paquete Antiterrorista» que ha introducido nuevos tipos delictivos e incrementado los poderes de investigación respecto de bancos, gestores de telecomunicaciones, sociedades financieras y compañías aéreas, restringiendo, entre otras garantías, la protección de los datos personales.

Se me permitirá que apostille tanto énfasis en la seguridad con la lacónica leyenda de una viñeta de humor (un tanto hiperbólica, es cierto, pero sólo lo propio del género): «Cuando oigo hablar de seguridad, me entra el pánico» ${ }^{33}$.

33 Publicada por «El Roto», en el diario El País el 22-9-2007. 


\section{REFERENCIA A ESPAÑA}

\subsection{De los estados constitucionales críticos a la normalización de la excepción}

Ya hemos apuntado que la opción seguida primeramente por los países democráticos fue la previsión constitucional de declaración de los estados de excepción y de sitio (o de guerra). La Constitución española lo hace en el artículo 116, el cual prevé tres situaciones constitucionales críticas diferentes: de alarma, de excepción y de sitio, estableciendo procedimientos y garantías en cada caso, de manera que no se altere sino lo imprescindible la vida democrática del país, y disponiendo en su artículo 55.1 qué derechos pueden ser suspendidos durante la vigencia de los estados de excepción y de sitio (no en los de alarma). Dice así el primero de los mencionados preceptos:

Art. 116. «1. Una ley orgánica regulará los estados de alarma, de excepción y de sitio, y las competencias y limitaciones correspondientes.

El estado de alarma será declarado por el Gobierno (...) por un plazo máximo de quince días, dando cuenta al Congreso de los Diputados, reunido inmediatamente al efecto y sin cuya autorización no podrá ser prorrogado dicho plazo. El decreto determinará el ámbito territorial a que se extienden los efectos de la declaración.

El estado de excepción será declarado por el Gobierno (...) previa autorización del Congreso de los Diputados. La autorización y proclamación del estado de excepción deberá determinar expresamente los efectos del mismo, el ámbito territorial a que se extiende y su duración, que no podrá exceder de treinta días, prorrogables por otro plazo igual, con los mismos requisitos.

El estado de sitio será declarado por la mayoría absoluta del Congreso de los Diputados, a propuesta exclusiva del Gobierno. El Congreso determinará su ámbito territorial, duración y condiciones.

No podrá procederse a la disolución del Congreso mientras estén declarados algunos de los estados comprendidos en el presente artículo, quedando automáticamente convocadas las Cámaras si no estuviesen en periodo de sesiones. Su funcionamiento, así como el de los demás poderes constitucionales del Estado, no podrán interrumpirse durante la vigencia de estos estados.

Disuelto el Congreso o expirado su mandato, si se produjere alguna de las situaciones que dan lugar a cualquiera de dichos estados, las competencias del Congreso serán asumidas por su Diputación Permanente.

La declaración de los estados de alarma, de excepción y de sitio no modificarán el principio de responsabilidad del Gobierno y de sus agentes reconocidos en la Constitución y en las leyes». 
Y el segundo:

Art. 55. «1. Los derechos reconocidos en los artículos 17, 18, apartados 2 y 3 , artículos 19, 20, apartados 1,a) y d), y 5, artículos 21, 28, apartado 2, y artículo 37, apartado 2, podrán ser suspendidos cuando se acuerde la declaración del estado de excepción o de sitio en los términos previstos en la Constitución. Se exceptúa de lo establecido anteriormente el apartado 3 del artículo 17 para el supuesto de declaración del estado de excepción».

Aunque no es uno de los objetivos de este trabajo hacer una análisis exhaustivo de la regulación de estas situaciones constitucionales ${ }^{34}$, sino, como veremos, su desplazamiento por otros métodos de restablecimiento del orden y de la normalidad, no podemos silenciar que, fiel a las pautas del constitucionalismo posbélico, nuestra norma suprema, junto a prever las declaraciones de dichos estados, con las restricciones de derechos que se reflejan en el texto del artículo 55.1, las reviste de importantes garantías, como son, entre otras,

a) la exigencia de concreción de las respectivas declaraciones con relación al ámbito territorial y a la duración de la medida;

b) aunque el precepto no lo dice así expresamente, debe entenderse que también es exigible igual concreción en los derechos que se suspenden, extremo que debe constar en la declaración y no dejarse a la actuación posterior del Gobierno;

c) la intervención del Congreso de los Diputados, bien para la declaración, bien para su autorización, bien, por último, para la autorización de la prórroga, según sea el estado declarado;

d) la indisolubilidad del Congreso de los Diputados durante la vigencia de cualquiera de los mencionados estados de anormalidad constitucional, y, en su caso, el ejercicio de sus competencias por su Diputación Permanente;

e) la convocatoria automática de las Cámaras si no estuvieren reunidas;

${ }^{34}$ Entre la amplia bibliografía sobre la materia, puede consultarse: CRUZ VILLALÓN, P.: Estados excepcionales y suspensión de garantías, Tecnos, Madrid, 1984; NAVAS CASTILLO, A.: «El Tribunal Constitucional en la declaración-autorización de los estados de alarma, excepción y sitio", en PAU Y VALLO, F.: Parlamento y Justicia Constitucional, Aranzadi, Navarra, 1987; LAFUENTE BALLE, J. M.: «Los estados de alarma, excepción y sitio», RDP, n. ${ }^{\circ}$ 30-31, UNED, Madrid, 1990; FERNÁNDEZ SEGADO, F.: "Artículo 55. La suspensión de derechos», en VV. AA.: Comentarios a las Leyes Politicas. Constitución española de 1978, 2. ${ }^{\text {e }}$ ed., Cortes Generales/EDERSA, vol. V, Madrid, 1996, pp. 627 ss. 
f) la no interrupción del funcionamiento de las Cámaras ni de los demás poderes del Estado;

g) la responsabilidad de los poderes públicos y de sus agentes.

(Sobre las garantías, como componente inexcusable de la juridicidad estatal, volveremos en un epígrafe ulterior.)

Ahora bien, acaso porque la Constitución española data de cuando ya el terrorismo estaba azotando intensamente nuestro país, hubo de enfrentarse a este fenómeno habilitando en el apartado siguiente del precitado artículo 55 la suspensión de ciertos derechos para personas, a titulo individual y en relación con investigaciones sobre la actuación de bandas armadas o elementos terroristas, no olvidándose tampoco de las garantías a las que esta grave decisión se somete.

Dice así el mencionado precepto:

Art. 55. «2. Una ley orgánica podrá determinar la forma y los casos en los que, de forma individual y con la necesaria intervención judicial y el adecuado control parlamentario, los derechos reconocidos en el artículo 17, apartado 2, y 18 , apartados 2 y 3 , pueden ser suspendidos para personas determinadas, en relación con las investigaciones correspondientes a la actuación de bandas armadas o elementos terroristas.

La utilización injustificada o abusiva de las facultades reconocidas en dicha ley orgánica producirá responsabilidad penal, como violación de los derechos y libertades reconocidos por las leyes».

De nuevo hemos de apreciar el doble estímulo que pesaba sobre el constituyente: de un lado, el hacer frente al fenómeno del terrorismo, puesto que no hay que olvidar que su trabajo, durante un año y medio, se desarrolló en un clima de intensa actividad de asesinatos y secuestros de ETA y de GRAPO; de otro, su sincera apuesta por construir un Estado de Derecho. Lo primero se desprende con derechura de la habilitación a los poderes públicos (quiérese decir al Poder Ejecutivo) a fin de que proceda a la suspensión de derechos para personas determinadas. Lo segundo está también explícito en el precepto, pero conviene resaltarlo ordenadamente:

a) Los derechos susceptibles de suspensión son únicamente los contenidos en los artículos 17.2 y 18.2 y 3 de la Constitución, a saber: las garantías concernientes a la detención preventiva, la inviolabilidad del domicilio y el secreto de las comunicaciones privadas.

b) Se establece una garantía legislativa consistente en la necesidad de regular esta previsión constitucional mediante una ley orgánica. 
c) Como asimismo se introduce una garantía jurisdiccional: la necesaria intervención de un órgano judicial para cada caso de suspensión individual de derechos.

d) Más aún: el precepto constitucional mantiene la garantía política de la responsabilidad del Ejecutivo en este cometido, que se sustancia mediante control parlamentario.

e) Y finalmente añade una garantía penal: la responsabilidad de esa índole por la utilización injustificada o abusiva de las facultades reconocidas al respecto en la ley orgánica.

Por su parte, el Tribunal Constitucional, resolviendo un recurso de inconstitucionalidad presentado contra la Ley Orgánica 9/1984, que desarrollaba el precepto indicado y regulaba la actuación de los poderes públicos contra las bandas armadas y los elementos terroristas, sostuvo:

1) Que ni la previsión constitucional ni su desarrollo legal atentan contra la igualdad, sino que quienes se encuentran inmersos en tal supuesto de hecho se colocan en situación diferente en relación con el Estado y la sociedad y, por tanto, el Ordenamiento español les da un tratamiento jurídico también diferente. (Aquí resuenan las tesis del Derecho penal del enemigo a las que hemos aludido en un epígrafe anterior.)

2) Que ese supuesto de hecho está integrado por dos ingredientes: «bandas armadas» $y$ «elementos terroristas», por lo que, si bien el terrorismo se manifiesta de forma armada, no toda persona ni banda armada es terrorista; por tanto, «el concepto de 'bandas armadas' — dice la sentencia- ha de ser interpretado restrictivamente y en conexión, en su trascendencia y alcance, con el de 'elementos terroristas' mencionado en el precepto constitucional». Igualmente, la jurisprudencia penal exige las notas de permanencia, carácter armado y entidad suficiente para producir terror por su gran incidencia en la seguridad ciudadana «que suponga también un ataque al conjunto de la sociedad democrática». Las cursivas, que son del autor de este trabajo, obedecen a que el precepto constitucional dice "actuación de bandas armadas o elementos terroristas», en tanto que el Tribunal ha cambiado la conjunción disyuntiva $\boldsymbol{o}$ por la copulativa $y$, lo que es una manipulación del texto de muy dudosa corrección, por mucho que responda al deseo de reducir los supuestos de aplicación del precepto constitucional por considerarlo excesivamente restrictivo de los derechos. 
3) La sentencia concluye con palabras de especial relevancia para nuestro estudio:

«Cualquier otra interpretación más amplia de la expresión 'bandas armadas', que permitiera la aplicación de la Ley Orgánica 9/1984... a personas y grupos que actuaran con armas, sin provocar el terror en la sociedad ni pretender alterar el orden democrático y constitucional del Estado de Derecho y sin ponerlo objetivamente en peligro, carecería de la cobertura constitucional del artículo 55.2» ${ }^{35}$.

Es reseñable el esfuerzo del Tribunal para contener al resto de los poderes públicos dentro de los márgenes de una más escrupulosa juridicidad estatal a la hora de desarrollar legislativamente el artículo constitucional de referencia y de que el Gobierno ejecute tal legislación.

Por último, es oportuno insistir con P. TENORIO ${ }^{36}$ en que España es el único país, de entre las democracias de nuestra cultura jurídica y política, cuya Constitución contempla explícitamente el terrorismo y las medidas estatales para hacerle frente: de un lado, se habilita la suspensión de determinados derechos a título individual ${ }^{37}$, pero, de otro, eso se hace sin abjurar del tono marcadamente garantista que preside todo nuestro texto fundamental; antes bien, se formulan de manera bastante explícita: intervención judicial, control parlamentario y responsabilidad penal de las autoridades por la utilización injustificada o abusiva de sus facultades incrementadas al efecto.

Como anota el autor citado, frente al retraimiento posterior del legislador, que no ha desarrollado dicho precepto como si fuera anómalo y seguramente porque las democracias se están inclinando por fórmulas diferentes, la opción de nuestra norma fundamental es una verdadera aportación al constitucionalismo ${ }^{38}$. Ello es así en la medida en que se prevé y se regula la situación al máximo nivel normativo, se precisa qué derechos pueden ser suspendidos y se incorporan las garantías concernientes a tales medidas. Con lo cual es innegable que gana la ju-

35 STC 199/1987, de 16 de diciembre.

36 TENORIO SÁNCHEZ, P.: Constitución, derechos fundamentales y..., ob. cit., y «Constitución y legislación antiterrorista», ob. cit., p. 560.

37 Cfr. CRUZ VILLALÓN, P.: «Suspensión individual de derechos», en ARAGÓN REYES, M. (coord.): Temas básicos de Derecho Constitucional, Civitas, Madrid, 2001, pp. 232 ss.; FERNÁNDEZ SEGADO, F.: "Artículo 55. La suspensión de derechos», ob. cit., pp. 627 ss.; VÍRGALA FORURIA, E.: «La suspensión de derechos por terrorismo en el Ordenamiento español», Revista Española de Derecho Constitucional, n. ${ }^{\circ} 40$, Centro de Estudios Políticos y Constitucionales, Madrid, 1994, pp. 564 ss.

38 TENORIO SÁNCHEZ, P.: Constitución, derechos fundamentales y..., ob. cit., y «Constitución y legislación antiterrorista», ob. cit., mismo lugar. 
ridicidad estatal más que con esas otras fórmulas comentadas más arriba. Habremos de volver de nuevo sobre ello.

\subsection{Dos épocas en la lucha antiterrorista española después de promulgada la Constitución}

Desde 1978 para acá ha habido dos épocas en la disciplina jurídica infraconstitucional del terrorismo: la primera abarca los años 1978 a 2002, fecha de la promulgación de la Ley Orgánica 6/2002, de Partidos Políticos; y la segunda, desde esta fecha hasta nuestros días, si bien la primera acaso pudiera desdoblarse en otras dos: de 1978 a 1988 y de esta fecha a 2002. Repasémoslas someramente a continuación.

\subsubsection{Primera época: coexistencia del Derecho penal del enemigo} con el principio de no intervención y el hipergarantismo

En esta primera época, hubo dos actitudes de signo contrario y simultáneas o casi simultáneas: una obedeció al principio de no intervención, a la observación acentuada del principio pluralista, entendido un tanto acríticamente, y a la aplicación escrupulosa (incluso algo más) de las garantías constitucionales; otra buscó alinearse con la corriente general de las democracias occidentales y llevó a la legislación ordinaria medidas propias de estados constitucionales críticos.

A fines de 1978, ya redactada la Constitución, pero antes de su promulgación, se aprobó la Ley de Partidos (de carácter ordinario por el obvio motivo apuntado de ser formalmente preconstitucional y no existir la ley orgánica como fuente del Derecho, después incorporada por el texto fundamental), que se limitó a establecer unos requisitos mínimos para la homologación de los estatutos de los partidos y un tenue sistema de control a priori y a posteriori que no funcionó nunca; más aún: había un decidido propósito de no ponerlo en práctica, de que ningún partido político quedara sin registrar y, por tanto sin legalizar por aplicación del control preventivo. El Registro de Partidos instaurado al efecto funcionó como mero trámite de comprobación de que los estatutos cumplían las formalidades requeridas, registrándose a continuación de forma poco menos que automática. La opinión publicada y la de los expertos que se pronunciaron al respecto defendía que el Registro no tenía que examinar el fondo de los estatutos por si de ellos se desprendía una causa de ilegalidad que impidiera su registro e incorporación a la democracia española, sino que tenía la 
obligación de registrar y después habría de ser la jurisdicción ordinaria la que asumiera la tarea de su ilegalización. No importaba que la Ley dijera otra cosa; eso es lo que había que hacer y eso fue lo que se hizo.

Resultado: Registro de más de 1500 partidos, algunos de los cuales no lo son, sino que están inscritos 20 veces, como partido de ámbito nacional y una vez más por cada Comunidad Autónoma, por Ceuta y por Melilla. La imagen atomizadora que ello refleja no se corresponde con la realidad. Además, si bien en la política local tienen relieve partidos pequeños, no sucede lo mismo con la política nacional, en la que sólo ha habido, desde 1977 hasta la fecha, de seis a nueve grupos parlamentarios en el Congreso de los Diputados; concretamente, seis es a la cifra a la que llegan en la actual legislatura después de hacer una interpretación del Reglamento del Congreso de los Diputados harto piadosa para con los vencidos.

Pero, por otro lado, en esta primera etapa también se aprobó la Ley Orgánica 11/1980, conocida usualmente como Ley Antiterrorista, sustituida en 1984 por la Ley Orgánica contra la Actuación de Bandas Armadas y Elementos Terroristas, y posteriormente, al igual que en otros países, se procedió a integrar la regulación antiterrorista en la legislación general: el Código Penal y la Ley de Enjuiciamiento Criminal, con lo que nuestro país se ha alineado en la corriente ya descrita de normalización de la excepción y adoptó el modelo de Derecho penal del enemigo. Asistíamos a la puesta en escena de la segunda actitud señalada.

De las dos prevaleció claramente la primera. Pues, efectivamente, de una parte, aquella legislación inicial, pese a sus deficiencias, no obligaba a una lectura tan condescendiente con las organizaciones cuyo verdadero programa era sintonizar y servir de plataforma al terrorismo, partidos que no eran sino grupos de delincuentes que no pretendían expresar el pluralismo político, sino pura y simplemente acabar con él y con el sistema que los cobija y les brinda tan sustanciosas garantías de inscripción y subsistencia, así como establecer un régimen monista, al menos en «su territorio». No cumplían, por consiguiente, las condiciones del régimen jurídico de los partidos expresado en el artículo $6^{\circ}$ constitucional y lo vulneraban con actuaciones muy graves.

Lo que vale tanto como asegurar que los motivos que ha habido ahora para combatir a Batasuna ya existían entonces tanto para, en primer lugar, haberse opuesto a su legalización cuanto para, años después, haber procedido a su ilegalización. No se hizo.

Acaso lo que más interesa de este periodo sea la diferente actitud del Gobierno y de los tribunales en torno a nuestro problema. Ambas actitudes nos presentan su cara y su cruz. 
A mi entender, el Ejecutivo —y ésta es su cara — supo ver el peligro que Herri Batasuna ${ }^{39}$ significaba para la democracia española y remitió en 1983 a la autoridad judicial la documentación que dicha formación presentaba en el Registro de Partidos del Ministerio del Interior e instó al Poder Judicial que se le denegara la inscripción.

Pudimos asistir entonces a un duro enfrentamiento entre los poderes Ejecutivo y Judicial. Los tribunales, como tutores de los derechos, fueron muy cuidadosos con sus garantías y, de una parte, desestimaron la iniciativa fundamentalmente por estimar que de la prueba documental no se desprendía ilicitud penal; de otro, fallaron en diversas ocasiones a favor de los inculpados y, cuando emergieron a la luz los crímenes de los GAL, condenaron a miembros del Gobierno y a jefes policiales a penas de cárcel. En esta misma dirección se puede recordar la interpretación restrictiva que el Tribunal Constitucional hizo del supuesto de hecho sobre el cual anuda el artículo 55.2 de nuestra norma suprema la suspensión individual de derechos constitucionales, según hemos anotado en una página reciente del presente estudio.

Y lo mismo hizo el cuando más adelante, en 1986, también desde instancia gubernamentales, se le demandó la ilegalización del ya registrado partido político Herri Batasuna; todo ello porque no quedaba en evidencia directamente su alineación con ETA ni su justificación del empleo de la violencia; es decir, apreció falta de pruebas suficientes, dado que de los estatutos de Herri Batasuna no se desprendían directamente estos extremos ${ }^{40}$. Eran años, los ochenta, en los que las garantías del pluralismo político, administradas con una ingenuidad y un buenismo dignos de mejor causa, primaban sobre otras consideraciones en nuestros dos más altos Tribunales, como hemos tenido ocasión de anotar anteriormente.

En consecuencia, Batasuna adquirió personalidad jurídica de partido con todos los beneficios jurídicos correspondientes, momento en el que ETA comenzó a tener financiación pública para continuar una sucesión infinita de asesinatos y de secuestros. A mayor abundamiento, varios de los preceptos de la Ley

39 Esta organización ha utilizado los nombres de Batasuna y Herri Batasuna, y su grupo parlamentario en el Parlamento Vasco también adoptó el nombre de Euskal Herritarrok. La ilegalización de la misma, a la que nos referiremos inmediatamente en el texto, alcanza a todas las denominaciones que haya adoptado o pueda adoptar en cualquier momento como partido político. Otra cuestión, a la que nos referimos en un ulterior epígrafe, es si esa ilegalización alcanza también a los grupos parlamentarios alineados políticamente con él.

40 Citaremos solamente, de un lado, las Sentencia de la Audiencia Nacional de 31-3-1984 y de la Audiencia Territorial de Madrid de 28-10-1985, y, de otro, las del Tribunal Supremo de 235-1984 y 7-7-1986, que confirmaron las anteriores respectivamente. 
orgánica de 1984 antes mentada fueron declarados inconstitucionales cuando alguno de ellos admitía una interpretación conforme a la Constitución ${ }^{41}$.

Aquel garantismo pusilánime resultó extremadamente nocivo en el terreno que analizamos teniendo en cuenta que tal organización ha sido el brazo político-institucional de ETA entonces, cuando revestía la forma de mero agregado de partidos, asociaciones y organizaciones sin estructura partidaria, lo fue más adelante, cuando fue legalizado como partido político unitario, y sigue siéndolo ahora, una vez ilegalizado.

La cruz de dicho Gobierno fue su cesión a la presión ambiental, que exigía mayor dureza en la política antiterrorista y auspició (o consintió, o no reprimió debidamente) la "guerra sucia» (en el mejor de los casos, se vio desbordado por ella), protagonizada por el denominado "GAL» (Grupos de Acción Antiterrorista) contra ETA, mientras el Presidente del Gobierno sostenía en el Parlamento que «el Estado de Derecho se defiende también en las cloacas» y que "lo importante no es que el gato sea blanco o negro, sino que cace ratones», lo que significaba una concesión ominosa a prácticas difícilmente conciliables con el Estado democrático de Derecho.

Además, posiblemente era mayoritaria en la opinión publicada en la mayoría de los medios de comunicación social, así como también en el seno de casi todas las fuerzas políticas la tesis de que era contraproducente la ilegalización de dicho partido y que era conveniente que ingresara en los órganos democráticos, como las Cortes Generales, el Parlamento autonómico Vasco y los Ayuntamientos de dicha Comunidad Autónoma, puesto que de esa manera iría integrándose en el sistema político y acostumbrándose a utilizar la palabra como instrumento de convicción, así como a pactar medidas para formar mayorías, etc. La realidad ha demostrado que no era verdad tanta belleza, que no hubo tal integración en el sistema democrático y que la financiación pública que obtenía dicho partido - o conglomerado de partidos — iba a parar en buena parte a las siempre voraces arcas de ETA.

De haber prosperado una de las dos iniciativas relatadas, el sistema democrático español habría obtenido algunas ventajas, o, por decirlo en forma negativa, habría evitado no pocos problemas. Pero, a mi juicio, los Tribunales Supremo y Constitucional no estuvieron a la altura de las circunstancias y su mal entendimiento del pluralismo político llevó al resultado de la plena inserción de Herri Batasuna (quiérese decir del terrorismo etarra) en el sistema democrático español, que era su mejor baza para intentar destruirlo. Y lo que es más sonrojante: con financiación de su propia víctima, la democracia española.

${ }^{41}$ STC 199/1987, citada. 
Desde entonces, el juego entre la separación aparente de Batasuna y ETA y el formalismo jurídico del Estado de Derecho español, que hacía como que disimulaba esa real conexión, a la que no oponía la firmeza deseable, presidió la actuación de los tribunales españoles durante dos décadas. Esta es su cruz en el asunto que tratamos y ésta es la historia de un desatino que no tiene paralelo en todo el mundo y en el que hemos vivido los españoles demasiado tiempo.

Con posterioridad, al igual que en otros países, se procedió a integrar la regulación antiterrorista en los dos grandes cuerpos normativos generales pertinentes en estos ámbitos: el Código Penal y la Ley de Enjuiciamiento Criminal. A ello respondieron la leyes orgánicas 3 y 4/1988 respectivamente. Esta legislación, cuya exposición pormenorizada no podemos hacer aquí, está animada por dos vectores: la necesidad, incluso la perentoriedad, de eliminar ese cáncer de la convivencia nacional y el insoslayable respeto a los principios del Estado de Derecho. Ahora bien, que después esta correcta concepción se haya plasmado en la práctica de manera irreprochable es ya otra cuestión; y lo mismo cabe decir de la actitud de los dos más altos tribunales. Pero el presente trabajo se mueve en el terreno de los principios.

A este respecto hay que señalar que la Ley de Seguridad Ciudadana, de 1992 (sólo parcialmente relacionada con el objeto de estas reflexiones, pero que traemos a colación como exponente del garantismo adoptado por nuestra jurisprudencia constitucional), también fue pulida de inconstitucionalidad por vulneración de la inviolabilidad de domicilio ${ }^{42}$. Acaso el Tribunal fue en esta ocasión demasiado sensible a la presión del clima de oposición a la ley creado en la opinión publicada, motivo por el cual despreció la posibilidad de hacer una sentencia interpretativa, como tantas veces había hecho y seguiría haciendo, en la que validara como flagrante delito el conocimiento cierto de la Fuerza Pública de que en determinado domicilio y en un momento concreto se estaba cometiendo un delito (normalmente de narcotráfico).

A mayor abundamiento, en 1999, fue anulada una sentencia del Tribunal Supremo que condenaba a los miembros de la Mesa Nacional de Herri Batasuna por un acto de colaboración con ETA no porque no hubiera habido tal colaboración, sino por considerar desproporcionada la pena mínima establecida por el Código Penal ${ }^{43}$.

Con todo, y esta es la otra faz del fenómeno que estudiamos, es evidente que nuestro país se ha alineado en la corriente ya descrita de «normalización» de la excepción. Y posteriormente la legislación española continuó la deriva iniciada

42 STC 71/1994, de 3 de marzo.

43 STC 136/1999, de 20 de junio. 
de endurecimiento creciente de las penas y de su administración penitenciaria, pudiéndose afirmar que también ha adoptado el Derecho penal del enemigo. A juicio de P. TENORIO, se dan en ella los tres elementos antes enunciados de este modelo punitivo ${ }^{44}$ :

a) Existen tipos delictivos que anticipan la punibilidad a actos que podríamos considerar como meramente preparatorios de hechos futuros; por ejemplo, los delitos de colaboración con bandas armadas o con organizaciones terroristas son propios del denominado Derecho penal de autor, que se adentra no en lo que el sujeto haya hecho, sino en lo que pueda hacer en su condición de terrorista.

b) Hay desproporcionalidad en las penas, como, por ejemplo, en el artículo 576 del Código Penal, que grava los actos preparatorios de colaboración con bandas armadas $\mathrm{u}$ organizaciones terroristas con una pena superior a muchas de las que se imponen por delitos contra la integridad física.

c) También se ha procedido a una restricción de las garantías procesales, tanto en la fase de instrucción, con la ampliación de las facultades policiales sin control judicial, como en el desarrollo del juicio oral, en que prima una cierta presunción de culpabilidad y pueden admitirse pruebas obtenidas ilícitamente.

En conclusión, el sistema político español seguía sin encontrar el equilibrio entre ambas tendencias.

\subsubsection{Segunda época: suspensión y disolución de los partidos políticos}

Ciertamente, la opinión de las principales fuerzas políticas de la nación cambió durante las legislaturas 1996-2000-2004. El disparate aludido en páginas anteriores comenzó a quebrar en 2002 precisamente por la acción casi simultánea del Poder Judicial y del Parlamento: aquél, actuando contra el denominado «entorno de ETA»; éste, mediante la aprobación de la Ley Orgánica 6/2002, de 27 de junio, de Partidos Políticos, que, además de disciplinar algo mejor (aunque no una gran cosa) el régimen jurídico de los partidos y su funcionamiento democrático interno, regula la suspensión y la disolución de éstos por diversos motivos, principalmente de crimen organizado y de terrorismo. Y am-

44 TENORIO SÁNCHEZ, P.: Constitución, derechos fundamentales y seguridad..., ob. cit.; cfr. también «Constitución y legislación antiterrorista», ob. cit., pp. 522-525. 
bos — Parlamento y Poder Judicial— vuelven a converger en su actividad por cuanto tales suspensiones e ilegalizaciones corresponden a la jurisdicción ordinaria. Veámoslo:

No fue al Gobierno, como órgano director de la política nacional, el que tomó la iniciativa de este afrontamiento del problema, sino la Oposición. A instancias del Partido Socialista Obrero Español, se concertó el Pacto por las Libertades y contra el Terrorismo, uno de cuyos frutos fue la citada ley orgánica. $\mathrm{He}$ aquí de nuevo el pacto (en este caso, el Pacto Antiterrorista, como así se reconoce usualmente) como modo de dirección política.

Añadamos, como ilustración de la convergencia antes señalada, que la tramitación de la Ley se cruzó con la actuación penal de la Audiencia Nacional, ya que mediante un auto del titular de su Juzgado número 5 se suspendió a Herri Batasuna y a todo el complejo de asociaciones y entes que componen lo que se ha venido en llamar el "entorno de ETA», por considerar que no son sino organizaciones a su servicio, es decir, que son realmente ETA con otra veste jurídica.

Promulgada la Ley de Partidos, validada ésta por el Tribunal Constitucional, como veremos en seguida, en una más que prevista sentencia interpretativa y obtenidas plúrimes pruebas de la clara relación e incluso identificación de Batasuna con ETA (coincidencia en las personas, importante financiación de ésta por aquélla, etc.), relación e identificación que Batasuna ni siquiera tomó la molestia de poner en cuestión con una simple condena de la violencia etarra, cosa que ni hizo en aquel momento ni todavía ha hecho, se procedió a su ilegalización.

Fue acordada por el Tribunal Supremo ${ }^{45}$, único órgano judicial competente para ello, e impugnada en dos recursos de amparo ante el Tribunal Constitucional, el cual los desestimó y confirmó, por tanto, la ilegalización ${ }^{46}$. Antes había habido una ilegalización de candidaturas de agrupaciones electorales y después siguieron otras tantas con ocasión de cada convocatoria electoral municipal y autonómica, igualmente recurridas y confirmadas ${ }^{47}$, salvo en una ocasión ${ }^{48}$.

Estas disoluciones han resultado extraordinariamente eficaces en la drástica reducción de la financiación de dicha organización y, por ende, de la de ETA,

45 STS de 27-3-2003.

46 SSTC 5 y 6/2004, de 16 de enero.

47 SSTC 85/2003, de 8 de mayo; 110 y 112/2007, de 10 de mayo.

48 STC 176/2003, de 10 de octubre. 
lo que ha resultado decisivo (junto a otros factores, en buena medida de índole internacional) en la casi total paralización de la actividad terrorista en los últimos años, lo que no significa que no tenga todavía capacidad para cometer atentados y provocar muertes, como ya ha hecho en varias ocasiones desde entonces.

Aun así, todavía era mayoritaria en la doctrina la tesis bienpensante y poco menos que oficiosa entre los constitucionalistas sobre la inconveniencia y muy probable antijuridicidad de la ilegalización de partidos políticos por significar una merma del pluralismo político; consiguientemente, la citada ley fue recibida con una gran división de opiniones, pero con una mayoría de juristas que la tildaba de inconstitucional ${ }^{49}$. Pero, frente a quienes consideraron en su momento que la ley era propia de una democracia militante (en el sentido más peyorativo posible de la expresión), e inconstitucional por eso mismo, además de que sería ineficaz, creo que se impone un juicio más ponderado ${ }^{50}$.

En realidad, más que ante una ley inconstitucional, estamos ante una que adolece de una desdichada redacción y de una torpe técnica legislativa, abundando en reiteraciones, oscuridades conceptuales y conceptos jurídicos indeterminados; pero unas y otras, oscuridades e indeterminaciones, resultan subsanables y determinables por vía de interpretación sin desdecir los principios constitucionales. Pues los criticados (con razón) conceptos jurídicos indeterminados no son por sí mismos una vulneración de la seguridad jurídica, sino, todo lo más, trabajo para abogados, fiscales y jueces; y también para nosotros, como estudiosos.

Lo deseable, ya lo sé, no es que se endosen al Tribunal Constitucional los problemas políticos más acuciantes, ni que las leyes se «salven» a base de sentencias interpretativas del mismo, pero, una vez que el Tribunal tiene el texto sobre su mesa, no puede eludir los problemas y su obligación es la de encontrar la constitucionalidad de la ley hasta donde pueda, máxime en este caso por su ele-

49 Cfr. mi trabajo «La inconstitucionalidad de los partidos políticos. A propósito de la Ley Orgánica 6/2002, de Partidos Políticos», ob. cit., pp. 39 ss.; y «Prólogo» a TAJADURA TEJADA, J.: Partidos políticos y Constitución, ob. cit.

50 Ibidem, mismos lugares. Cfr., entre una amplia bibliografía, TAJADURA TEJADA, J: Partidos políticos y Constitución, Madrid, 2004, y bibliografía allí citada. Cfr. igualmente VÍRGALA FORURIA, E.: «La STS de 27 de marzo de 2003 de ilegalización de Batasuna: el Estado de Derecho penetra en Euskadi», Teoría y Realidad Constitucional, n. ${ }^{\circ}$ 12, UNED, Madrid, 2003-2004, pp. 618 ss.; ÁLVAREZ CONDE, E.: El derecho de partidos, Colex, Madrid, 2004, pp. 206-280; y FERNÁNDEZ-MIRANDA CAMPOAMOR, A., y FERNÁNDEZ-MIRANDA CAMPOAMOR, C.: Sistema electoral, partidos politicos y Parlamento, Colex-UNED, Madrid, 2003, pp. 47-79. 
vada gravedad política; labor que, sin embargo y como es lógico, tiene como límites los propios principios constitucionales que trata de cohonestar la jurisprudencia constitucional.

Casi estaríamos por decir que, de cara al recurso de inconstitucionalidad presentado por el Gobierno Vasco, esto era lo previsible que hiciera y lo que hizo el Tribunal Constitucional ${ }^{51}$, según el cual la especial relevancia que tienen los partidos políticos por las funciones públicas que cumplen justifica que la Constitución les imponga condiciones que no les exige a las asociaciones comunes ${ }^{52}$. Lo mismo - hemos de añadir — que acaso justifique, en positivo, su financiación casi exclusiva a cargo del erario público.

A mi manera de ver, por tanto, resulta evidente que el Tribunal estaba dispuesto a validar la Ley de Partidos, pues anular por inconstitucional algunos de sus pasajes, siendo posible salvarlos, aun con esfuerzo, comportaba un paso atrás en la lucha contra el terrorismo que el Tribunal no estaba dispuesto a dar; o, por mejor decir, no estaba dispuesto a significarse como el órgano que lo diera. Se percibe aquí que, pese a todo su poder, el Tribunal Constitucional no sólo es un órgano menesteroso (como dijo en su día RUBIO LLORENTE), pues nunca actúa de oficio y ha de esperar a que otros órganos o miembros de órganos lo pongan en marcha, sino que, llegado el caso, no puede eludir el ser corresponsable de la dirección política del Estado. Éste ha sido el caso que nos ocupa. En fin, en medio de cierta polémica entre estudiosos y creadores de opinión, la ley quedó incardinada a nuestro Ordenamiento jurídico.

Viniendo ahora al significado político de la ley, lo positivo de la misma, a mi modo de ver, reside en que el Estado de Derecho español (Legislativo y Judicial actuando de modo independiente pero convergente, como ya he señalado) ha decidido dejar de lado de una vez los complejos que sobre este particular ensombrecían la democracia española, que no lograba disipar los recelos que su política antiterrorista despertaba por doquier por el recuerdo de la represión antinacionalista del régimen autocrático de Franco Bahamonde. Como es bien sabido, en muchos países, incluso socios y aliados de España, se seguía viendo a ETA y a su entorno como un puñado de valientes luchadores por la libertad de su pueblo, como un grupo de nacionalistas románticos perseguidos y maltratados por el Estado español, y con angelical conciencia (vamos a dejarlo ahí y a no suponer otros estímulos ni predisposiciones), daban asilo político a asesinos

51 STC 48/2003, de 12 de marzo. Tanto en esta sentencia como en la 5/2004, de 16 de enero, se insiste en la defectuosa redacción de la ley.

52 STC 48/2003, citada, FJ 9. 
etarras huidos de la Justicia española y dificultaban hasta el extremo su extradición cuando ésta les era solicitada ${ }^{53}$.

De manera que, a pesar de que una medida de este alcance tiene una lectura fácil — demasiado fácil — de limitación o cercenamiento parcial del pluralismo político, tiene otra, en este caso mejor fundada, de remoción de un notable obstáculo precisamente para el pleno desarrollo del pluralismo político. Pues no enriquece dicho pluralismo quien asesina, secuestra y extorsiona a los ciudadanos; o bien atenta contra edificios institucionales, mercados, aeropuertos y colegios; o bien es cómplice o encubridor de tales actividades, todo ello con el propósito evidente de amedrentar a la población y a la autoridad instituida y dinamitar (nunca mejor dicho) el régimen democrático que le da cobijo y de cuyas garantías y financiación se beneficia.

Por último, el Gobierno Vasco acudió al Tribunal Europeo de Derechos Humanos impugnando la ilegalización de Batasuna arguyendo, entre otros extremos, que Ley de Partidos que la hacía posible vulneraba derechos reconocidos en el Convenio Europeo. El recurso fue inadmitido por falta de legitimación acti$\mathrm{va}^{54}$. Quedaba por ver lo que este Tribunal resolvería sobre los recursos individuales o de agrupaciones de electores que se le elevaron, todos ellos provenientes del «entorno de Batasuna», sobre el rechazo de sus candidaturas a diversos procesos electorales, con cuya ocasión el Tribunal tendría que pronunciarse seguramente sobre el fondo del asunto.

Lo verdaderamente significativo de esta no tan intrincada cuestión es que el dicho Tribunal Europeo, en varias sentencias de 30 de junio de 2009, ha encontrado conformes al Convenio las actuaciones de los poderes públicos españoles. En una de ellas resuelve que Herri Batasuna, con uno u otro nombre, era un soporte implícito del terrorismo de ETA y que su ilegalización era una necesidad social imperiosa y proporcionada a un fin legitimo; incluso dice que la Ley de Partidos es precisa, lo que ya es más discutible ${ }^{55}$. En otras dos estima que no vulneran el Convenio Europeo de Derechos Humanos la anulación de las candidaturas presentadas posteriormente a las elecciones locales de $2003^{56} \mathrm{y}$ a las europeas de

53 No es ocioso recordar, como contraste, que, en su día, en Alemania e Italia ciertos delincuentes de parecido perfil al de los etarras, pertenecientes a las bandas Mader Meinhof y Brigadas Rojas respectivamente, aparecieron muertos (algunos en establecimientos penitenciarios) y tales episodios apenas merecieron la "primera» de los medios de comunicación durante unos días.

54 ATEDH de 6 de febrero de 2004.

55 STEDH de 30-VI-2009, caso Herri Batasuna y Batasuna contra España.

56 STEDH de 30-VI-2009, caso Etxeberria, Barrena Arza, Nafarroako Autodeterminazio Bilgunea y Aiarako y otros contra España. 
$2004^{57}$ por diversas organizaciones alineadas igualmente con ETA. Y no deja de ser remarcable, frente a la pusilanimidad de la doctrina mayoritaria española, que el Tribunal Europeo haya resuelto por unanimidad.

\section{REPERCUSIONES ELECTORALES DE LA DISOLUCIÓN O SUSPENSIÓN DE UN PARTIDO POLÍTICO}

No empecen a la reflexión que acabamos de hacer acerca de los logros de la Ley de Partidos las dificultades que ha encontrado a veces en su aplicación, y son remarcables, en cambio, sus repercusiones positivas, unas de carácter electoral y otras de índole político-institucional. Abordamos en este epígrafe las primeras y las institucionales más adelante, con el paréntesis, en sí mismo trascendental, de las repercusiones financieras de la ilegalización y/o de la suspensión.

\subsection{La proliferación de candidaturas sucedáneas y su laboriosa ilegalización}

Fueron ilegalizadas cientos de candidaturas correspondientes a agrupaciones electorales secuaces de Batasuna en las elecciones municipales de 2003 y 2007 y en las elecciones autonómicas de 2005 y 2009 . Y todo hace presumir que la experiencia se reproducirá en cada convocatoria electoral. Sin embargo, algunas lograron pasar el filtro, por lo que lograron alargar la vida institucional de Batasuna.

Estas dificultades se deben a que, en algunas ocasiones, la constitución y composición de las candidaturas se ha hecho con mayores cautelas para poder pasar el listón de la ley. Es posible que, de haber sido ésta mejor elaborada y mejor acompañada de una reforma ad hoc de la Ley Orgánica del Régimen Electoral General (reforma que al cierre de estas páginas se está iniciando), hubiera permitido a los tribunales trabajar más desahogadamente, sin unos plazos tan perentorios como hábilmente instrumentalizados por las mentadas agrupaciones y partidos, lo cual habría redundado en una más eficaz lucha contra el terrorismo. Pero lo ha sido bastante y continúa siéndolo en la actualidad.

Ello fue que, tras la ilegalización de Batasuna y de muchas agrupaciones electorales (no todas), se ha procedido del mismo modo y con igual resultado contra el Partido Comunista de las Tierras Vascas (PCTV) y Acción Nacionalista Vasca (ANV). El primero por ser un sucedáneo de Batasuna creado apresuradamente tras la ilegalización de éste, que logró burlar el control en las elecciones

\footnotetext{
57 STEDH de 30-VI-2009, caso Herritarren Serenad contra España.
} 
autonómicas de 2005 y ha detentado escaños en el Parlamento Vasco desde dicha fecha hasta 2009. El segundo es un partido que, si bien databa de setenta años atrás y era legal, aunque sin actividad ${ }^{58}$, ha sido reactivado y absorbido por Batasuna para las elecciones municipales de 2007.

En ambos casos se ha actuado a través de la doble vía existente, la penal y la habilitada por la Ley de Partidos. La vía penal fue adoptada como medida cautelar por un Juzgado de la Audiencia Nacional en el curso de la instrucción seguida contra los miembros más destacados de dicho partido, que en realidad lo son de Batasuna. La introducida en nuestro Ordenamiento por la Ley de Partidos ha sido acordada en ejecución de la sentencia que resolvió la disolución de Batasuna, por entender que se trataba del mismo partido con otra faz y que, por tanto, su actividad era tan ilegal como si la realizara la propia Batasuna. Todas las sentencias del Tribunal Supremo anulando candidaturas electorales, con una sola excepción, fueron ulteriormente confirmadas por el Tribunal Constitucional en respuesta a sendos recursos de amparo ${ }^{59}$.

La excepción: en 2009, el Tribunal Constitucional estimó el recurso de amparo presentado por la coalición «Iniciativa Internacionalista-La Solidaridad entre los Pueblos», cuyas candidaturas habían sido anuladas por el Tribunal Supremo. Consideró el supremo intérprete de la Constitución que no había indicios suficientes de su carácter continuador de los partidos ilegalizados ${ }^{60}$, consideración que, sin embargo, se vio inmediatamente desmentida por la propia Batasuna.

\subsection{Posible inclusión en las listas electorales de personas condenadas por delitos de terrorismo}

La condena penal por delito de terrorismo no comporta, dice el TC, una causa de inelegibilidad imprevista por la Ley Electoral, sino un criterio para valorar el comportamiento del partido examinado; pues, si éste incluye en sus can-

${ }^{58} \mathrm{Y}$ al que, por eso mismo, bien se le podría haber cancelado su inscripción en el Registro de Partidos, reduciéndoselo a la condición de mera asociación, como he indicado en páginas precedentes, si no fuera porque la actitud de los poderes públicos españoles, y en especial del Judicial, ni siquiera se lo plantearon; peor aún, ni siquiera eran ni son conscientes de que jurídicamente puede hacerse.

59 Cfr, entre otras, SSTC 85/2003 de 8 de mayo; 5, 6 y 99/2004, de 16 de enero y 25 de mayo; 68/2005, de 31 de marzo, y 110 y 112/2007, de 10 de mayo. Remito al excelente libro de P. J. TENORIO SÁNCHEZ: TConstitución..., ob. cit.

${ }^{60}$ STC 126/2009, de 21 de mayo. 
didaturas regularmente a personas que sufren o han sufrido tal condena, ello podría significar una solidaridad con el terror. Ciertamente, ninguna persona está obligada a retractarse de lo hecho, pero, si no lo hace, el partido debe saber que el incluirla reiteradamente en sus listas electorales puede tener la lectura dicha.

No obstante, el precepto correspondiente de la Ley de Partidos sólo tiene proyección hacia el futuro y se juzga a partir de una trayectoria de conjunto y dilatada en el tiempo. He aquí otro elemento interpretativo de esta sentencia (fundamento jurídico 13), sin el cual la ley quedaría al borde de la inconstitucionalidad porque podría significar un cercenamiento ilegítimo del derecho de participación política.

\section{REPERCUSIONES FINANCIERAS}

Es una tesis generalmente admitida que la financiación de los partidos políticos a cargo del Estado (tomado este término en su sentido más amplio y apropiado, que engloba a las Comunidades Autónomas y a los entes locales), financiación que es común en todas las democracias, tiene su más cabal justificación en las funciones que cumplen éstos, y que en nuestro caso vienen explícitamente formuladas en el artículo $6^{\circ}$ del texto fundamental. Ello, por su parte, les confiere una especial relevancia, que los diferencia netamente de las asociaciones comunes. Pero, como contrapartida, también todo ello justifica que la Constitución les imponga unas condiciones que no les exige a las demás asociaciones. Como ya hemos adelantado, el Tribunal Constitucional ha hecho suya esta interpretación, que es pacífica en la doctrina ${ }^{61}$.

Las disoluciones han resultado extraordinariamente eficaces en la drástica reducción de la financiación de dicha organización y, por ende, de la de ETA. Este estrangulamiento financiero de Batasuna-ETA se opera por dos vías: la merma de la financiación pública y la liquidación de su patrimonio ${ }^{62}$.

\subsection{Merma o pérdida de la financiación pública}

Es bien sabido que la principal fuente de financiación de los partidos políticos en España es el erario público, el cual les hace abonos por varios conceptos.

${ }^{61}$ STC 48/2003, cit., FJ 9.

${ }^{62}$ Cfr. la muy reciente obra La ilegalización de partidos políticos en el Ordenamiento español, de M. IGLESIAS PÉREZ, Comares, Granada, 2008. 
Uno de ellos es financiación electoral, conforme a la cual, además de pagos en especie (o, mejor, ahorro de gastos), se valoran tanto los votos como los escaños obtenidos, a tantos euros cada uno, una vez que se superan ciertos mínimos, y lo mismo en las elecciones municipales y autonómicas que en las generales y al Parlamento Europeo. Por eso, la ilegalización de un partido, y la subsiguiente prohibición y, en su caso, también ilegalización de las formaciones políticas (sean partidos o agrupaciones de electores) que pretendan suceder a aquél en fraude de ley, tiene como consecuencia la merma (e incluso, en el límite, la pérdida total) de su financiación pública, lo cual desangra su economía hasta la extenuación, dada la escasa cultura de "militancia contributiva» existente en España y la precariedad de otras fuentes de financiación privada.

Se comprende que no otra cosa fue lo que Batasuna-ETA pretendió en su momento abandonando su forma asociativa atomizada, integrada por grupúsculos autónomos, e instando su legalización como partido. Aparte, como es de suponer, de entrar en las instituciones y hacer política desde ellas, que prometía ser tanto más eficaz cuanto más se insertara en los equipos de gobierno de las mismas (y todo ello mientras ETA realizaba la suya con secuestros y bombas), además de eso, digo, obtener la financiación pública que por la participación electoral y esa participación institucional en grupos municipales y parlamentarios obtendría de la Hacienda Pública.

Pues bien, tras las ilegalizaciones comentadas, cabe apuntar algunas de estas pérdidas:

a) Pérdida de la diferencia entre la financiación electoral (por votos y por escaños) que hubiera obtenido la «marca» $\mathrm{HB}$ con la obtenida por otras afines, principalmente PCTV, en las elecciones municipales de 2003 y de 2007.

b) Igual ajuste se ha producido en las elecciones autonómicas de 2005 y de 2009.

c) Pérdida de la diferencia entre la asignación a los grupos municipales que hubiera constituido HB en 2003 y en 2007 y la obtenida respectivamente por PCTV y ANV, diferencia más abultada en esta segunda ocasión por la mayor dificultad que están teniendo ahora las candidaturas sucedáneas.

d) Dígase lo mismo referido al grupo parlamentario que hubiera constituido HB y el constituido por PCTV en 2005, diferencia que es aún mayor en la legislatura vigente.

Obviamente, estas pérdidas han beneficiado la financiación de los demás partidos y grupos municipales y parlamentarios en la proporción en que hayan 
captado los votos antes favorables a $\mathrm{HB}$, e incluso en el caso de que éstos hayan engrosado la abstención, puesto que en ambos supuestos se han incrementado los efectivos de otros grupos parlamentarios.

\subsection{Liquidación patrimonial}

En segundo lugar, la ilegalización de un partido puede comportar (y en nuestro caso comporta) la liquidación de su patrimonio, y el de ETA-Batasuna no era escaso. Lo cual, aparte de otras consideraciones jurídicas tiene fácil explicación si tomamos en consideración el muy oscuro origen de dicho patrimonio, que es en parte fraudulento ( el indebidamente recibido de las arcas del Estado) y en parte delictivo por haber sido obtenido por la criminal extorsión que eufemísticamente denomina «impuesto revolucionario».

Esta liquidación patrimonial y la prohibición de celebrar negocios jurídicos, con la correspondiente nulidad o anulabilidad de los que celebre, hace que sus finanzas se reduzcan a esas extorsiones a empresas, que, efectivamente, se han recrudecido desde la ilegalización de Batasuna. Pero esto, a su vez, tiene un precio en la opinión pública y el correspondiente cansancio de la sociedad vasca, e incluso de sus propios votantes.

\section{REPERCUSIONES POLÍTICO-INSTITUCIONALES}

\subsection{Relación de algunos efectos habidos}

La ilegalización de Batasuna también ha dado ya resultados muy tangibles en este terreno:

a) El Parlamento Navarro aplicó el auto del Juzgado número 5 de la Audiencia Nacional, disolviendo el Grupo Parlamentario de Batasuna y retirándole las subvenciones. Incluso dejó en suspenso las iniciativas anteriores de este grupo.

b) También se aplicó, al menos en Navarra, a los grupos municipales.

c) Batasuna cambió el nombre de algunos de sus grupos municipales en unos sitios sí y en otros no, dependiendo, claro está, del juego de mayorías y minorías de cada Ayuntamiento.

d) Batasuna cambió sus sedes a pisos privados o a asociaciones locales. 
Y es que, aunque en estos dos últimos movimientos haya no poco de fraude, se ve que la ley y los autos judiciales infunden respeto. El terrorismo valora que la lucha contra él va en serio, se siente acosado, se repliega y se ve con menos fuerza.

\subsection{Conservación de los escaños}

En cambio, los diputados elegidos bajo la candidatura de Batasuna en las elecciones autonómicas de 2001 permanecieron en sus escaños hasta el final de la legislatura en 2005 , pese a que la ilegalización del partido tuvo lugar en 2004, lo que no deja de ser, o de parecer, una cierta ineficacia del Ordenamiento jurídico al respecto. De ahí que tengamos que enfrentarnos con esta cuestión siquiera sea brevemente.

Tal permanencia tiene su fundamento en el instituto del mandato representativo. Me he ocupado de este problema desde hace mucho tiempo y remito a uno de mis trabajos ${ }^{63}$, en el que se critica la doctrina del Tribunal Constitucional Federal alemán, el cual sostuvo en 1952 —en un caso que hubo de resolver sobre la declaración de inconstitucionalidad y correspondiente disolución del Partido Neonazi- que, una vez ilegalizado un partido, queda rota la relación representativa entre el electorado y los diputados que se encuentran en la situación descrita. Tal consecuencia no figuraba expresamente en ningún precepto jurídico, sino que fue "construida» por el Tribunal mediante interpretación. Repitió la doctrina en 1956, ahora contra el Partido Comunista y con apoyo en la ley electoral convenientemente modificada. A mi juicio, ni con ley ni sin ley puede sostenerse tal doctrina en una democracia representativa.

Nos hallaríamos en una situación diferente si lo estableciera la propia Constitución. Pero entonces estaríamos ante un modelo diferente de democracia representativa, en la que los ciudadanos no eligen candidatos personales, sino partidos, y no habría diputados electos propiamente dichos, y hasta serían fungibles por sesiones, según fuera el asunto a tratar en la Cámara; el Parlamento, por tanto, no estaría integrado por diputados, sino por grupos parlamentarios, e incluso éstos no serían más que secciones especializadas e igualmente fungibles de los partidos. A la postre sobrarían todos los diputados menos los portavoces, y el Parlamento funcionaría como Junta de Portavoces, en la que cada uno tuviera tantos votos como escaños hubiera ganado el partido en las elecciones co-

63 TORRES DEL MORAL, A.: «Crisis del mandato representativo en el Estado de partidos», Revista de Derecho Político, n. ${ }^{\circ}$ 14, UNED, Madrid, 1982, pp. 7-30.

(C) UNED. Revista de Derecho Politico

N. ${ }^{\circ} 78$, mayo-diciembre 2010, págs. 95-160 
rrespondientes, etc., etc. Todo lo cual tendría una consecuencia muy positiva: haber acabado con el problema del transfuguismo, puesto que, como los escaños pertenecerían a los partidos, el diputado tránsfuga perdería su escaño lógicamente; y, de camino, también se habría acabado con el diputado independiente, lo que tiene todo su sentido, porque en el modelo descrito, un diputado que pensara por sí mismo resultaría obsceno.

Entiendo que todavía no hemos llegado a este tipo de parlamentarismo ni de democracia. Ni siquiera en Alemania, por lo que ni siquiera en ella es admisible la doctrina de su Tribunal Constitucional. Hay quien ha defendido este modelo de parlamentarismo ${ }^{64} \mathrm{y}$ de democracia representativa, pero, independientemente de posiciones de lege ferenda, lo que sí niego con rotundidad es que ya estemos en ellos.

En fin, trayendo de nuevo el asunto a España y al Parlamento Vasco, lo único procedente después de las disoluciones e ilegalizaciones comentadas era $-\mathrm{y}$ así se hizo - aguardar al término de la legislatura y, mientras tanto, seguir financiando con el erario público, mal que nos pese, a esos «representantes» del terrorismo y esperar que los demás grupos parlamentarios procuraran que esos diputados perjudicaran lo menos posible a la democracia con su actuación en la Cámara. Esta última aspiración, lo confieso, roza el idealismo. Pero no a causa de mi desviada argumentación, sino porque, frente a BURKE y CONDORCET, a los padres fundadores del Estado constitucional y representativo, a James MILL, que afirmaba que la representación era el gran invento de los tiempos modernos que resolvía todas las dificultades de la convivencia política, o de K. LÖWENSTEIN, que la considera una invención tan importante como la máquina de vapor, la electricidad, el motor de explosión y la fuerza atómica, el mandato representativo muestra la modestia de su alcance provocando aporías como la que comentamos. Por eso está en crisis, aunque, en realidad, está en crisis desde que nació.

\subsection{La no disolución del grupo parlamentario}

Esas perplejidades de la democracia representativa cobran un color aún más intenso en el problema que ahora abordamos, que, por eso mismo, es de un gran interés jurídico y se ha planteado en la lucha de la democracia española contra el

${ }^{64}$ Cfr. BiRBAUM, P., HAMON, F. y TROPER, M.: Réinverter le Parlement, París, 1977; CHANDERNAGOR, A.: Un Parlement pourquoi faire?, París, 1967, y MASCLET, J. C.: Un député pourquoi faire?, París, 1982. 
terrorismo de ETA, concretamente en lo concerniente al grupo parlamentario Socializt Abertzaleak. En tanto se resuelve el recurso de amparo actualmente en curso, avanzaré mi tesis e intentaré justificarla a continuación: el mandato del Tribunal Supremo al Parlamento Vasco para que disolviera el mencionado grupo parlamentario no está ayuno de dificultades jurídicas, hasta el punto de que bien podría sostenerse que es incorrecto.

Decidida por el Tribunal la disolución de dicho grupo parlamentario por considerarlo un correlato del Partido Comunista de las Tierras Vascas, lo comunicó al Parlamento Vasco para que procediera a su disolución; la Mesa del Parlamento se negó a hacerlo aduciendo cuestiones procedimentales y de competencia, y el Presidente del Parlamento dijo en plena sesión que en él no había ningún grupo parlamentario ilegal. Los miembros de la Mesa fueron denunciados ante el Tribunal Superior de Justicia de dicha Comunidad Autónoma por desobediencia al Tribunal Supremo y condenados, y su recurso ante el Tribunal Supremo, desestimado. Actualmente se encuentra en espera de resolución del recurso de amparo interpuesto por los interesados.

De otro lado, tengamos en cuenta que, conforme hemos visto en el apartado anterior, diputados individuales afectados conservan sus escaños y por disposición reglamentaria pasan al Grupo Mixto junto a otros diputados de diferentes ideologías y conectados a otras fuerzas políticas. Por eso, el alcance real de la disolución es de financiación y de protagonismo parlamentario, por cuanto ambos menguan considerablemente en tal circunstancia. Pero no se evitaría la permanencia de dicho grupo en la Cámara.

Mis dudas jurídicas residen en los siguientes argumentos:

a) La negativa a disolver el referido grupo parlamentario ha sido tomada mediante una resolución de la Mesa del Parlamento Vasco, no por un acto de sus miembros individualmente considerados.

b) Los actos de decisión o resolución de un órgano parlamentario en el ejercicio de sus funciones constitucional y reglamentariamente conferidas (y más aún si son del Pleno) son actos del Parlamento.

c) La Mesa del Parlamento, en el ejercicio de las funciones que tiene estatutaria o reglamentariamente conferidas, actúa en nombre del Parlamento; mejor dicho, actúa como Parlamento porque, en ese cometido, es el Parlamento; consiguientemente, la mencionada resolución denegatoria de la disolución del grupo parlamentario Socializt Abertzaleak es un acto del Parlamento Vasco.

d) De otro lado, los Parlamentos autonómicos, como todos los Parlamentos dignos de este nombre en democracias representativas que lo sean real- 
mente, gozan de autonomía reglamentaria, que se vierte en varios ámbitos: organización, funcionamiento, presupuesto y gobierno. Hasta tal punto es esto así que se erige en uno de los criterios para catalogar al régimen de referencia como demoliberal o no, incluso como más o menos demoliberal ${ }^{65}$.

e) Como el régimen instaurado por la Constitución española de 1978 es un Estado social y democrático de Derecho, autonómico, democrático representativo y monárquico parlamentario, sus instituciones parlamentarias gozan de la mencionada autonomía. Así lo establecen los respectivos Estatutos de Autonomía y así lo desarrollan sus reglamentos.

f) Por consiguiente, la orden de disolución del referido grupo parlamentario dictada por el Tribunal Supremo al Parlamento Vasco vulnera el principio de autonomía parlamentaria por cuanto se ingiere en su organización y funcionamiento y quiere regularlo heterónomamente. Por tanto, dicho Parlamento (o el órgano interno competente, como es la Mesa) no está obligado a cumplirla por antijurídica.

g) Quiérese decir entonces que, si el Parlamento Vasco no disuelve el grupo parlamentario, éste sigue existiendo hasta el final de la legislatura, como así ha sido. De ello se derivará una responsabilidad política, pero ésta se dirime en otro ámbito, no en el judicial, pues, por lo que acabamos de apuntar, no se trata de una responsabilidad penal de los individuos componentes de la Mesa del Parlamento. (Por cierto, tal responsabilidad política ya se ha hecho patente, de momento, en las últimas elecciones generales de 2008, en las que el Partido Nacionalista Vasco ha bajado en votos y en escaños, y también en las elecciones autonómicas vascas del año siguiente, tras las que dicho partido se ha visto superado, a la hora de formar Gobierno por una coalición entre el Partido Socialista y el Partido Popular. Pero ésta, obviamente, es otra cuestión.)

h) Por lo demás, si los miembros de la Mesa del Parlamento Vasco hubieran tenido la precaución de adoptar la decisión de no disolver al citado grupo parlamentario mediante votación secreta y hubieran acordado, también en secreto, dividir los votos con el simple cuidado de que no malograr el resultado apetecido, ¿contra quién o quiénes actuaría el Tribunal Supremo?; ¿no es entonces un sinsentido actuar contra dichos miembros cuando no han tomado tan elementales precauciones?

${ }^{65}$ Cfr. mi trabajo «Artículo 72.1. La autonomía de las Cámaras y los Estatutos parlamentarios», en ALZAGA VILLAAMIL, O. (dir.): Comentarios a las leyes políticas. Constitución española de 1978, vol. VI, EDERSA, Madrid, 1989, pp. 389 ss., y bibliografía allí citada. 
i) El debate podría haber tenido un último envite si el Parlamento Vasco hubiera aprobado una propuesta de reforma de su Reglamento a fin de que, en lo sucesivo, la disolución de un grupo parlamentario en iguales o similares condiciones a las anteriores sea acordada por el Pleno. Como no prosperó $^{66}$, ahí termina el problema, al menos por ahora. Pero de haber sido aprobada, ¿quién o quienes resultarían penalmente responsables por negarse a disolver el grupo parlamentario: todos los diputados o sólo quienes hubieran votado negativamente a la disolución? ¿Y si se procedía a una votación secreta? No se trata de que la propuesta indicada fuera una mera argucia para blindarse de cara a ulteriores ocasiones, que lo era y estaba hábilmente urdida, sino de que, más propiamente, estamos ante un problema de autonomía parlamentaria, uno de los pilares del Estado democrático de Derecho.

\section{9. ¿ES LA ESPAÑOLA UNA DEMOCRACIA MILITANTE?}

Por todo lo anteriormente expuesto, puede deducirse que, salvo en lo concerniente a la escaramuza recién relatada, mi juicio sobre esta última andadura de los tribunales Supremo y Constitucional no es negativo, aunque sus resoluciones sean matizables aquí o allá. En cambio, sí es rechazable la insistencia de ambos tribunales en que adoptan tales resoluciones pese a que en España no existe una democracia militante. Me he referido a ello en otros trabajos, a cuyos argumentos me acojo libremente a continuación ${ }^{67}$.

El recurso del Gobierno vasco argüía que la Ley Orgánica de Partidos se instala en una posición de democracia militante, entendida esta locución en el sentido de que impone sus valores negando los diferentes y los opuestos, de lo cual resultaría una obvia negación del pluralismo político. Nuestros dos altos tribunales dan por bueno ese concepto de democracia militante esgrimido por el re-

${ }^{66}$ Para mayor barroquismo, fue rechazada por la falta de apoyo de los diputados del PCTV, que era precisamente el grupo cuestionado.

${ }^{67}$ Me he pronunciado sobre este pseudoproblema en mi trabajo «Democracia militante», en VV.AA.: Derecho constitucional del siglo XXI, Thomson-Aranzadi, Navarra, 2006, pp. 209-224; en otros varias veces citados más arriba: «La inconstitucionalidad de los partidos políticos...», ob. cit., pp. 39 ss., y «Prólogo» a la obra de J. TAJADURA TEJADA Partidos políticos y Constitución, ob. cit.; así como en mis obras Estado de Derecho y democracia de partidos, Publicaciones de la Facultad de Derecho de la Universidad Complutense, 2. ${ }^{\text {e }}$ ed., Madrid, 2004, pp. 282 ss.; Principios de Derecho Constitucional Español, Publicaciones de la Facultad de Derecho de la Universidad Complutense, 5. ${ }^{\text {e }}$ ed., Madrid, 2004, vol. I, pp. 426 ss. 
currente, pero niegan que la española lo sea porque la Constitución no contiene cláusulas de intangibilidad y, por tanto, permite su reforma total.

Ambos tribunales yerran al aceptar tal concepto, que nos ha llegado de la mano de la doctrina alemana de entreguerras y que es inmensamente mayoritario en la doctrina española. Fue LÖWENSTEIN, en 1937, quien primero utilizó la expresión «democracia militante» para argumentar que la democracia de Weimar sucumbió ante los enemigos de la libertad precisamente por no ser militante, dictamen en el que puede verse una preferencia por que la democracia sí lo sea.

Pero la expresión fue puesta en relación con la conocida concepción kelseniana de la democracia como simple método de gobierno ${ }^{68}$. Extrapolando este concepto, todo lo que, excediéndose de ello, impida o entorpezca el libérrimo, competitivo y aséptico procedimiento de adopción de decisiones y de gobierno (libre competición en las urnas, acceso a los equipos de gobierno en condiciones de igualdad, etc.) resulta ser no democrático o antidemocrático, máxime si ese entorpecimiento o impedimento se hace por la vía penal (sola o acompañada del juicio de constitucionalidad del partido en cuestión), por más que los grupos que resulten entorpecidos o impedidos en tales supuestos sean los que pretenden y están intentando de hecho la aniquilación de ese mismo sistema democrático.

De este modo, la locución democracia militante ha terminado siendo entendida entre nosotros de modo muy peyorativo, como democracia intransigente, inquisitorial, coercitiva, intolerante y represora de valores ajenos y de las formaciones políticas que los profesan; o, lo que es lo mismo, una democracia contradictoria, puesto que estaría cercenando antidemocráticamente el pluralismo político. Y este solo motivo ha sido más que suficiente para que ambos tribunales y la corriente mayoritaria de la doctrina española se hayan colocado a la defensiva. Torpe opción.

A la hora de encontrar una explicación plausible a aquella primera toma de posición abstencionista e hipergarantista de nuestros tribunales, creo que es plausible utilizar la hipótesis del tic antifranquista adoptado por el constituyente y después incorporado más o menos oficiosamente por diversas instituciones y por la opinión publicada. No vamos a seguir aquí esta línea de investigación por obvias razones de espacio, pero a buen seguro que la encontraríamos verificada en un buen manojo de preceptos constitucionales: si el régimen de Franco Bahamonde fue monista, la democracia española «debe» ser pluralista a todo evento; si aquél censuró la libertad de comunicación pública, ésta le confiere posición

${ }^{68}$ Véase alguna precisión a esta lectura de KELSEN en la introducción de este mismo estudio. 
preferente en el sistema constitucional de los derechos; si entonces se encarcelaba a los objetores de conciencia, ahora se los libera y se los dota de amparo constitucional e incluso algunos la pretenden extender a todos o casi todos los ámbitos y funciones de la vida nacional (jueces hay que se proclaman objetores de conciencia a la ley que están constitucionalmente obligados a aplicar). Ciertamente muchas de estas opciones del constituyente son plausibles, pero siempre con la prudencia de no hacer de dicha confrontación un simple tic que se dispara como un resorte por reflejo condicionado; porque eso no es indicativo de talante democrático, sino de irreflexión.

Dicho lo cual y de modo acaso sorprendente para los tiempos que corren, podríamos concluir remedando a Lenin: si éste reprochó al izquierdismo ser la enfermedad infantil del socialismo, bien podríamos nosotros decir ahora que el democratismo es la enfermedad infantil de la democracia.

A mi juicio, la democracia es, sí, un método de gobierno, pero también mucho más que eso: es un régimen político, entendiendo por tal la forma política que responde a la cláusula esencial del pacto social fundante de la comunidad política. Todavía más, la democracia es una forma de vida (así la calificaba C. J. FRIEDRICH, además de cómo forma política, en una obra ya clásica $\left.{ }^{69}\right)$. Este otro concepto de democracia, contra lo que pudiera parecer, no es ajurídico en absoluto, puesto que se trata de una forma de vida basada en valores, en la defensa de los derechos y en la voluntad de seguir siendo democracia; y todo ello regulado por un Ordenamiento jurídico democrático en su elaboración, en su aprobación, en su aplicación y en su control. Dicho en breves palabras: la democracia no es un régimen éticamente neutral o agnóstico, sino que profesa unos valores, una ética que se vierte en el Ordenamiento jurídico.

Por consiguiente, tampoco son éticamente agnósticas la democracia española ni la Constitución que le da forma jurídica. Si el Estado democrático español, como dice el primer precepto de nuestro texto fundamental, propugna unos valores (vale decir que los defiende y ampara, según el Diccionario de la Real Academia Española), los poderes públicos, que están sometidos a la Constitución (según recuerda esta misma, acaso innecesariamente, en su artículo 9.1), no pueden permanecer indiferentes cuando un partido intenta suprimirlos o cercenarlos mediante la extorsión y el crimen, o bien cuando otras organizaciones sociales son cómplices o encubridoras de dicho partido, le prestan su voz y su voto en las instituciones, no condenan sus crímenes, proveen a su financiación con la que ellos obtienen del erario público, encubren a sus autores, dedican calles a terroristas, los

${ }^{69}$ FRIEDRICH, C. J.: La democracia como forma política y como forma de vida, 2.a ed. cast., Tecnos Madrid, 1966. 
reconocen oficialmente como hijos predilectos de su ciudad de nacimiento, o, en fin, declaran día de fiesta local el de un atentado terrorista.

El argumento de que la democracia española no es militante porque la Constitución no tiene cláusulas de intangibilidad, permitiendo su reforma total es muy endeble. Pues, si Constitución y democracia significan lo que creo que significan, para que una reforma sea constitucional es necesario que lo sea en su principio, en sus procedimientos y en su desembocadura. Por tanto, una operación que desemboca en un régimen no constitucional no es una operación constitucional; y tampoco es una reforma democrática la que da como resultado un régimen autocrático y totalitario por mucho que haya sido aprobada por los representantes de la soberanía nacional o incluso directamente por su titular en referendo nacional. Sostener lo contrario significa que estamos hablando sólo de una de las dimensiones de la democracia, la meramente formal o formalista, como método de adopción de decisiones, obviando la sustancial, que es su apuesta por la dignidad y la libertad disponiendo todo el aparato estatal y todo el Ordenamiento jurídico al servicio de su garantía.

Por eso, si, en aras del pluralismo, la democracia tolera en su seno la actividad de partidos y agrupaciones cuyos miembros asesinan, secuestran y extorsionan, siembran el terror entre quienes no piensan, no actúan o no votan como ellos y están dispuestos — más aún: tienen como norte de actuación- liquidar el propio régimen democrático que los legitima, entonces está dejando crecer en su seno un peligrosísimo cáncer hasta su última fase de metástasis.

La democracia española propugna como valores superiores la libertad, la justicia, la igualdad y el pluralismo político. Y propugnar es, defender, amparar, proteger $^{70}$. Sin embargo, propugnar el pluralismo político no significa defender toda clase de organizaciones políticas, puesto que no caben en él ni las paramilitares, ni las secretas, ni las creadas para delinquir, ni las terroristas, ni las que sirven a éstas de cómplices o tapaderas.

La democracia protege, ampara y defiende unos valores éticos que le dan vida y en los que se fundamenta, y persigue y combate a quienes los atacan o embisten contra ellos. Puede y debe hacerlo. ¿Qué diferencia hay entre defender unos valores y militar en ellos frente a quienes han decidido exterminarlos mediante el terror? Sólo un juego de palabras, pura logomaquia. Si a ello se le llama

70 Propugnar es defender, amparar, según reza el Diccionario de la Real Academia Española; los diccionarios de sinónimos y antónimos amplían su significado a proteger, defender, amparar y ayudar, por contraposición a atacar, embestir y asaltar; y el Diccionario de uso del español de María Moliner matiza: actualmente se emplea sólo con el significado de "defender o apoyar para que se haga cierta una cosa por ser convenientes (cursiva mía). 
democracia militante, puede y debe haber democracia militante y eso no le resta ni un punto a su carácter democrático. Más aún, tiene que haberla porque no merece el nombre democracia aquella a la que no le importa dejar de serlo. ¿Democracia militante española? Claro que sí, como cualquier otra que se precie, diga lo que diga la vieja, añeja y obsoleta doctrina recibida, y hayan dicho lo que hayan dicho los tribunales españoles Constitucional y Supremo, que tampoco en esto han estado muy finos.

Por eso, entendida la democracia al modo como hemos expuesto en líneas precedentes, toda democracia es militante, debe serlo y no puede dejar de serlo. En materia de valores, toda democracia que se precie debe ser militante y fuerte en su propia defensa, y no neutra, indigente, aséptica, indiferente, displicente, confusa, escéptica o agnóstica; y a la hora de defenderlos, no puede aparecer perpleja o impasible, y menos aún ser negligente o quedarse inerme (por desarme unilateral o autodesarme); pero ni siquiera puede mostrarse ante sus enemigos tímida, acomplejada, temerosa, apocada, indolente, abúlica, dubitativa, indecisa, vacilante, pusilánime, irresoluta o apática. Porque ése puede ser su fin. Por el contrario, tiene que creer en lo que propugna y defenderlo con fuerza, con toda la fuerza y por todos los medios que le permita el ser un Estado democrático de Derecho.

Después de creer que me batía en solitario en este erial de ideas, reconforta leer en sentido convergente al que suscribo el libro de A. y C. FERNÁNDEZ MIRANDA, que se enfrentan a la presente polémica con gran vigor dialéctico y mejor prosa que la mía. Espigaré solamente unos párrafos de gran sensatez y expresividad: 1) Los asesinatos de ETA «son agresiones sustanciales al fundamento axiológico del sistema democrático» ${ }^{71}$. 2) «Ninguna democracia coherente puede aceptar la legitimidad de la destrucción de los supuestos de la democracia» ${ }^{72}$.3) Ya existe además en España, en la legislación penal, «una interpretación de la Constitución española como la de una democracia axiológica», puesto que, en efecto, el artículo 510 del Código Penal condena la provocación discriminatoria por razones, entre otras, de etnia, raza, origen nacional, etc., lo cual es pacíficamente aceptado por la sociedad española «sin que se haya presentado ningún recurso de inconstitucionalidad»; por tanto, nada de novedoso tiene que se declare ilícito un partido político «que sistemáticamente haga suyo, en su comportamiento, y no sólo en su opinión, tal discriminación » ${ }^{73}$. Así, pues, la idea de

${ }^{71}$ FERNÁNDEZ-MIRANDA CAMPOAMOR, A., y FERNÁNDEZ-MIRANDA CAMPOAMOR, C.: Sistema electoral, partidos políticos y Parlamento, ob. cit., p. 73.

${ }^{72}$ Ibidem, p. 69.

73 Ibidem, p. 73. 
la democracia «no militante» $\mathrm{o}$ «inerme» no se compadece muy bien con tales preceptos $^{74}$.4) Por todo ello, «la Constitución ha de ser necesariamente beligerante contra las actividades antidemocráticas y en España lo es incluso contra las ideas... cuando éstas son propaladas con el objetivo de hacerlas realidad, transformando el orden político" ${ }^{75}$.

Más recientemente, E. ÁLVAREZ CONDE se ha sumado al escepticismo respecto del carácter científicamente inatacable del concepto de democracia militante que sustentan la doctrina mayoritaria española, el Gobierno Vasco, el Tribunal Constitucional y el Tribunal Supremo y juzga inadmisible la tesis de que la democracia española no es militante, sino inerme, porque no está expresamente formalizado en nuestro Ordenamiento constitucional el núcleo esencial en el que pudiera cifrarse la misma; y, en fin, califica de estéril la polémica al respecto ${ }^{76}$.

Finalicemos el epígrafe con dos consideraciones de distinta índole, una teórica y otra práctica. Por lo que se refiere a la construcción teórica del concepto de democracia militante, la aporía en que se ve atrapada gran parte de la doctrina española se resuelve no negando que la española lo sea, sino negando que el adjetivo «militante» descalifique a la democracia, es decir, negando, por insostenible, la corrección de tal concepto por los argumentos arriba esgrimidos, que son, a mi juicio, concluyentes. Lo curioso es que muchos juristas españoles defienden las dos tesis contradictorias: la existencia de valores y principios inconstitucionales implícitamente inmodificables y la imposible ilegalización de partidos que atenten contra ellos incluso mediante el terror; y esta posición es todavía menos sólida que la antes descrita.

Y, lo que es más evidente, los tribunales Supremo y Constitucional españoles están ellos mismos insertos en la democracia militante española y, con sentencias como las referidas, están sirviéndola y militando claramente en ella. Pues, en efecto, media un claro trecho, como hemos podido apreciar, entre dos actitudes adoptadas por ellos en cada una de las dos épocas que hemos analizado en un epígrafe anterior.

A grandes rasgos, antes de la Ley de Partidos se mantuvieron en posiciones garantistas hasta la minucia. Baste recordar episodios como la desestimación del intento que hizo el Gobierno de impedir el registro de Herri Batasuna como partido político, y más tarde de una similar iniciativa para ilegalizarlo; la declaración de inconstitucionalidad de algún pasaje de la Ley de Seguridad Ciu-

74 Ibidem, p. 76.

75 Ibidem, p. 78.

76 ÁLVAREZ CONDE, E.: El Derecho de partidos, Colex, Madrid, 2005, pp. 122-143; las dos consideraciones citadas corresponden a las páginas 141 y 142 respectivamente. 
dadana que admitía una interpretación conforme a la Constitución, etc. Recuérdese, por el contrario, que, cuando en los años 2005 a 2007 había esperanzas de un resultado positivo en las negociaciones para que ETA abandonara las armas, cundió la tesis, auspiciada por el Fiscal General del Estado y algunos jueces, con un más que discutible apoyo en el artículo 3..$^{\circ}$ del Código Civil, de que la legislación había de ser aplicada conforme a la nueva realidad (y, por tanto, de una forma lenitiva) en los numerosos procesos que miembros de la organización terrorista tenían pendientes y en sus regímenes penitenciarios: huelga de hambre de De Juana Chaos y resolución judicial por la que se accedía a que cumpliera en su domicilio el resto de su condena, etcétera.

En cambio, llegado el momento, se «salvó» la Ley de Partidos mediante una sentencia interpretativa, pero, sobre todo, después de fallida una vez más la esperanza de un final negociado de la violencia, ambos tribunales mostraron una actitud mucho más cercana a las posiciones gubernamentales y parlamentarias, buscando no entorpecer la vital lucha antiterrorista de la mayoría gobernante avalada en las urnas, mostrándose mucho más rigurosos con ese entramado criminal. Recuérdense, entre otros casos, la condena y encarcelamiento del destacado miembro de Batasuna Arnaldo Otegui, uno de los sedicentes impulsores de la negociación, y el nuevo hostigamiento al terrorista De Juana Chaos, al que antes se había cuidado con cierta deferencia.

No obstante, ya hemos advertido, a fuer de objetivos, que ése ha sido su comportamiento a grandes rasgos; pero, en aras de la verdad, tampoco estamos ante un grosero cambio de actitud. Baste con recordar que durante el proceso negociador fueron anuladas no pocas candidaturas sucedáneas de Batasuna en diferentes convocatorias electorales; y, por otra parte, el Tribunal Constitucional ha mantenido el mismo criterio acentuadamente garantista a la hora de apreciar si la jurisdicción ordinaria ha agotado los medios de prueba para disipar suficientemente las denuncias de tortura que los recurrentes en amparo (habitualmente miembros de ETA) suelen hacer (está en su manual de instrucciones) contra las Fuerzas de Seguridad del Estado. Es decir, el Tribunal Constitucional no se pronuncia sobre si ha habido tortura o no porque no es ése el objeto de los recursos, sino que evalúa si el órgano judicial, en el proceso a quo, ha agotado los medios de prueba para disipar toda duda al respecto ${ }^{77}$.

Más aún: casi un año y medio después de haberse roto la tregua y el proceso negociador, o lo que e igual, en plena época de hostigamiento a ETA, el Tribunal Constitucional estimó un recurso de amparo interpuesto por la coa-

77 SSTC 224/2007, de 22 de octubre, y 52, 63 y 69/2008, de 14 de abril, 26 de mayo y 23 de junio respectivamente, entre otras.

(C) UNED. Revista de Derecho Politico

N. ${ }^{\circ}$ 78, mayo-diciembre 2010, págs. 95-160 
lición electoral «Iniciativa Internacionalista La Solidaridad entre los Pueblos» contra su ilegalización ${ }^{78}$. Estimó el Tribunal que no había pruebas ni indicios de su carácter secuaz de Batasuna o Herri Batasuna a pesar de la opinión generalizada de que sí lo era (puesto que había muchos indicios de ello, aunque no pruebas), opinión que se vio confirmada días después de la sentencia, al pedir Batasuna el voto para dicha coalición.

Por lo demás, estoy persuadido de que, con esta sentencia, el Tribunal Constitucional no sólo ha rendido un servicio directo a la democracia española, sino también indirecto, como puede observarse en la casi inmediata sentencia del Tribunal Europeo de Derechos Humanos ${ }^{79}$ que desestima por unanimidad el recurso de Batasuna contra su ilegalización, en el que, de paso, quedaba cuestionada asimismo la Ley de Partidos. Y lo considero así porque, si ciertamente no podemos afirmar que el referido amparo haya determinado el sentido final del pronunciamiento de la Corte de Estrasburgo, sí parece que la contundencia de la unanimidad de ésta responde a su inequívoca convicción de que el Estado español no profesa una democracia ciegamente militante ni pluralista a medias o a conveniencia, sino que es cabalmente un Estado democrático de Derecho.

En definitiva, el Ordenamiento y los más altos tribunales españoles no han llegado, ni de lejos, a una drástica intensificación de normas, medidas e interpretaciones tendentes a preservar la democracia de todo atisbo de riesgo. En la defensa de la democracia hay grados, como los hay en la lucha contra la delincuencia, en la duración de las penas de privación de libertad, en la defensa de la vida y en la admisión o no de la pena de muerte, en las libertades informativas, en la igualdad de género, en las formas de matrimonio admitidas y en todas las parcelas del Ordenamiento.

Puede objetarse ciertamente que reducirlo todo a una ponderación de grados y de límites relativiza la cuestión e impide obtener conclusiones tajantes e inequívocas del análisis, pero cabe replicar a esta alegación con un doble argumento: en primer lugar, que matizar es más difícil, pero, por eso mismo, mejor y más científico que lanzar pronunciamientos tajantes e incontrovertibles; y en segundo término, que se puede y se debe diferenciar con claridad entre un régimen, como el federal alemán, que a los tres años de existencia ilegaliza un partido y, sin previsión alguna en su Ordenamiento, priva de su escaño a los diputados elegidos en las candidaturas del mismo ${ }^{80}$ y otro, como el español vigente, que:

78 STC 126/2009, de 21 de mayo.

79 STEDH de 30-VI-2009, caso Herri Batasuna y Batasuna contra España.

${ }^{80}$ Remito a las breves pero sustanciosas pinceladas que P. TENORIO dedica a la opción de la República Federal de Alemania a la defensa de la democracia en su obra Constitución..., en prensa. 
a) se decide a ilegalizar un partido, respetando los escaños electoralmente obtenidos por sus candidaturas ${ }^{81}$, después de treinta años, mil muertos y cientos de sentencias condenatorias de sus jefes y miembros tras unos juicios con todas las garantías;

${ }^{81}$ Ya en pruebas este estudio, me veo obligado a introducir en él, como nota, una breve referencia a la reforma de la Ley Electoral que, al parecer, prepara el Gobierno consistente en que, una vez ilegalizado un partido por motivos de terrorismo, los diputados y concejales elegidos en sus candidaturas han de condenar tal actividad si quieren conservar su escaños. Me pronunciaré sobre ello más detenidamente en un trabajo posterior, pero su importancia me persuade de adelantar algo en éste porque afecta de lleno a lo hasta aquí escrito.

Diré sin dilación que mi opinión es contraria a lo pretendido y los motivos son los siguientes:

1. Dicha reforma introduce una causa de ruptura de la relación representativa no contemplada ni explícita ni implícitamente en la Constitución, por más que su artículo 23 remita a la ley (orgánica) la regulación del ejercicio del derecho de participación política y del de acceso a los cargos públicos.

2. Las tachas que sobrevengan después de las elecciones no pueden ser aplicadas con efectos retroactivos para ilegalizar unos votos expresos y válidos en el momento electoral, sino sólo, en su caso, de cara al futuro.

3. También en hipótesis, el cuerpo normativo apropiado sería el reglamento de la Cámara respectiva, bien parlamentaria, bien municipal, provincial o insular.

En efecto, una vez celebradas las elecciones, proclamados los candidatos electos y resueltos todos los recursos habidos contra todas las fases del proceso que pudieran ofrecer dudas, éste no es revisable por una elemental aplicación del principio de conservación de los actos jurídicos y políticos.

Aceptando en envite gubernamental como mera hipótesis dialéctica, la operación no sería la de revisar la elección, sino la de perfeccionar la situación jurídica del diputado o concejal supuestamente afectado, o, por mejor decir, de subsanar una condición resolutoria sobrevenida. La elección está hecha y no se puede repetir: es historia. Lo que en realidad se estaría cuestionando es la condición de diputado o concejal de quienes fueron elegidos en determinadas candidaturas, duda que, según la noticia que tengo del propósito del Gobierno, éste entiende que se podría disipar con una simple declaración. Declaración que obviamente no tendría valor electoral alguno, sino que, siempre en hipótesis, perfeccionaría la situación jurídica del representante afectado a la vez que perfeccionaría la composición de la Cámara correspondiente.

Aclarado el mencionado aspecto formal, insisto en que sería inimaginable que ese diputado o concejal perdiera su escaño por no hacer la declaración referida y, sin embargo, ganara un nuevo escaño en las elecciones siguientes de la mano de otro partido todavía no ilegalizado y todo ello sin haber movido un músculo en la dirección deseada por la reforma comentada.

Del mismo modo, tampoco son revisables, y no creo que el Gobierno y su grupo parlamentario lo pretendan, los actos parlamentarios ni las votaciones habidas en las que hayan participado dichos diputados, ni las leyes aprobadas por sus votos, ni los Gobiernos censurados o, al contrario, confirmados con esos mismos votos. La Historia no es revisable. La sentencia ilegalizadora sólo puede tener efectos de cara al futuro. Ya comprendo que esta solución no es satisfactoria por cuanto permite la prolongación de la vida de una fuerza política ilegalizada. Pero el Estado de Derecho tiene sus exigencias. 
b) que, aun disuelto dicho partido, no ilegaliza otro, secuaz del anterior, por impedirlo la observancia exquisita del sistema constitucional de garantías, y

c) que se toma el agotador trabajo, en cada convocatoria electoral, de analizar cientos de candidaturas fraudulentas de organizaciones sucedáneas del partido ilegalizado, por si, en aras del pluralismo, pudiera «salvar» alguna ${ }^{82}$ aun a sabiendas de que lo más probable, e incluso seguro, es que la financiación obtenida por la misma en función de los votos y escaños alcanzados, procedente del dinero de todos los españoles, terminará en las arcas de la organización terrorista para mejor seguir asesinando, secuestrando, extorsionando, aterrorizando y buscando derribar la democracia para implantar en «su territorio» una autocracia totalitaria con un grado cero de pluralismo.

Pidiendo excusas por el énfasis puesto en el argumento, estoy persuadido de que nadie negará las diferencias. De manera que, si la democracia militante es vituperable, habrá que empezar por señalar a otras antes que a la española.

\section{EL ESTADO DEMOCRÁTICO DE DERECHO, ÚNICA RESPUESTA}

\subsection{Terrorismo, réplica estatal y valores}

Ya hemos comentado cómo una errónea gestión del problema del terrorismo lleva frecuentemente a sortear y vulnerar los derechos y las garantías propias de un Estado democrático de Derecho; y todo ello por entender, como ya hemos comentado, que, si la tortura es eficaz para obtener una información válida en esa lucha, no debe ser excluida de los instrumentos utilizados por el Estado. Ahora bien, con tal planteamiento no sólo se quebrantan flagrantemente los derechos humanos que toda democracia dice defender, sino que se corre el riesgo de fortalecer la cohesión interna de los grupos terroristas y su posición internacional e invertir el juicio de la opinión pública mundial (y aun de la propia nacional) al respecto, o, por lo menos, de relativizar su autoridad moral; es decir,

${ }^{82}$ En el mismo proyecto de ley orgánica aludido en la nota anterior se incluirá también una ampliación del plazo de denuncia de las candidaturas y de resolución, por parte del Tribunal Constitucional de los recursos de amparo que normalmente presentan los partidos ilegalizados y las candidaturas anuladas. 
puede suscitar la emergencia de cierto sentimiento de equidistancia, conforme al cual ninguna de esas dos fuerzas en litigio alcanza una opinión pública totalmente favorable ni en el interior del país ni en el ámbito internacional; y eso, se mire como se mire, es un resultado negativo —al menos parcialmente negativo- para el Estado democrático de Derecho, y, por tanto, parcialmente positivo para el terrorismo.

En España sabemos, por episodios de infausta memoria, que el terrorismo no sólo busca matar a un guardia civil o poner una bomba en un supermercado, sino forzar al sistema político y jurídico que combate a fin de llevarlo a la contradicción de los valores que éste dice defender. Es para los terroristas más importante socavar los cimientos del sistema del Estado social y democrático de Derecho que el cobrarse una víctima, porque ello comenzaría a dar una razón a su lucha.

Podríamos traer a colación algún episodio poco edificante ${ }^{83}$, pero es preferible apuntar a los conceptos. Y en este terreno tiene gran calado el hecho de que el Tribunal Europeo de Derechos Humanos condenara a Turquía por la sentencia a muerte dictada por su Poder Judicial contra Ocalam, lo que aconteció con violación de un buen puñado de derechos humanos, dado que Turquía había tenido incomunicado al procesado durante una semana antes del juicio, no le garantizó la asistencia letrada, prolongó el periodo de detención demasiado tiempo, no le proporcionó un juicio justo pues el órgano judicial que lo juzgó no constituía un tribunal imparcial, etc. ¿Quién ha quedado más en entredicho, el Estado turco u Ocalam? No nos pronunciemos abiertamente: digamos que los dos. Pero esto ya es, a todas luces, una derrota del Estado de Derecho.

D. SANSÓ-RUBERT opone dos visiones de la democracia, una pragmática y otra ético-jurídica ${ }^{84}$. Para la primera, los derechos humanos no pueden reducir las posibilidades de respuesta de las democracias frente a sus enemigos; por eso es lícito recortarlos si resulta necesario. Para la segunda, la democracia pierde su significado si los derechos son revocables para sus enemigos en tales situaciones. Para aquélla, los compromisos de la democracia con la dignidad y los derechos no se extienden a sus enemigos, porque éstos, en realidad, son «enemigos de la raza humana» $y$, para combatirlos, el fin justifica los medios. Para ésta, dichos compromisos son universales y alcanzan, sin maquiavelismo posible,

${ }^{83}$ Es conocido el episodio en el que el juez Sr. Polanco, actuando en funciones de tal en la Audiencia Nacional, espetó a un inculpado de terrorismo: «Si no estuvieras esposado, te daría un par de hostias» (sic). Podría valer como anécdota, pero no lo creo. Ése no puede ser el comportamiento de un miembro de uno de los principales poderes del Estado de Derecho en su legítima lucha contra el terrorismo. Por muy harto que estuviera de las impertinencias de dicho individuo, no es ésa la forma en que un juez debe tratar a un justiciable. Fue debidamente sancionado.

${ }^{84}$ SANSÓ-RUBERT PASCUAL, D.: «Seguridad vs. libertad...», ob. cit., pp. 98-99. 
a todas las personas ${ }^{85}$. La primera parece estar de acuerdo con el pensamiento de Clausewitz:

«Aquel que se sirve de la violencia sin reparar en sangre tendrá ventaja si el adversario no lo hace. Con eso marca la ley para el otro, y así ambos ascienden hasta el extremo sin que haya más barrera que la correlación de fuerzas inherente. Así es como hay que ver esta cuestión, y es una aspiración inútil, incluso falsa, dejar fuera de consideración la naturaleza de un elemento por repugnancia ante su crudeza».

La segunda, con el Club de Madrid:

«Las medidas de lucha contra el terrorismo deberán respetar plenamente los principios internacionales sobre los derechos humanos y el Estado de Derecho. No existen soluciones sencillas (...) Sólo la libertad y la democracia serán capaces de derrotar finalmente al terrorismo. Ningún otro sistema de gobierno puede reivindicar mayor legitimidad, ni existe otro sistema con mayor capacidad de respuesta ante las demandas políticas» ${ }^{86}$.

Cabe una tercera postura algo más circunstanciada: aquella que considera que, por motivos graves de terrorismo, podría admitirse una cierta relajación en la vigencia de los derechos, como mal menor, para defender la democracia, siempre que dicha medida esté dirigida a un objetivo concreto, sea aplicada restrictivamente, empleada como último recurso y sometida al escrutinio propio de una sociedad democrática ${ }^{87}$. De ahí la previsión de los estados de anormalidad constitucional y de ahí también que esa reducción de garantías se realice únicamente en dichas situaciones y no se incorpore a la legislación general; dicho de otro modo: que no se proceda a una estabilización de la excepción ni de la situación anormal.

En realidad, esta eventual actitud de un régimen no resuelve el problema, que se convierte en $s u$ problema cada vez que adopte alguna medida. Es una tercera vía desgarrada ante un problema que no sabe resolver porque acaso no tiene nunca una buena solución a priori. ¿Es irresoluble entonces?

Enfrentado a este problema y visto lo insatisfactorio de las respuestas jurídicas tradicionales, a saber, la declaración de estados constitucionales críticos, fundamentalmente, en terminología española, los de excepción y sitio (a los que

${ }^{85}$ Ibidem, mismo lugar.

${ }^{86}$ CLUB DE MADRID: Comunicado final de la Cumbre sobre Democracia, Terrorismo y Seguridad, 11 de marzo de 2005, cit. por SANSÓ-RUBERT PASCUAL, D.: «Seguridad vs. libertad...", ob. cit., pp. 108, nota 49, y 112, nota 55.

87 Ibidem, p. 100. 
podría añadir el estado o la situación de guerra), algún autor, como M. ROSENFELD, propone añadir el que denomina estado de tensión, intermedio entre los de normalidad y excepción, que se produce cuando la comunidad se ve desestabilizada y sometida a diversas presiones, como sucede en caso de terrorismo $^{88}$. En términos similares, B. ACKERMAN, habla de un nuevo estado de emergencia $^{89}$. La idea directriz de estas fórmulas es la de que a este estado intermedio le corresponden medidas intermedias, es decir, que no lleguen a la gravedad de las adoptadas en un estado de excepción.

\subsection{Exigencias de los principios democrático y de juridicidad estatal}

Pues bien, a la hora de arbitrar tales medidas, no se puede desconocer la naturaleza del régimen constitucional democrático. Porque la relación entre la libertad y el poder político, si no se ha invertido, sí se ha transformado en el paso del Estado liberal al Estado social y democrático de Derecho. Ello se pone de relieve fundamentalmente en que, de ser los derechos, en su mayoría, libertades-resistencia, esto es, repelentes de toda injerencia del poder público en ellos, convirtiéndose así en una coraza protectora respecto de la eventual arbitrariedad del leviatán, hemos pasado a un tipo de Estado —el social y democrático de Derecho- que es también, y muy fundamentalmente, un Estado de derechos.

Tal identificación entre Estado y derechos implica que éstos no son ya para aquél un simple muro de contención, sino un ámbito idóneo para su actividad protectora y promotora a fin de hacerlos reales y efectivos, por decirlo con términos afines al artículo 9.2 de nuestro texto constitucional. Todo ello sin perjuicio de la actuación estatal decidida y firme cuando estos derechos sean conculcados no ya por la autoridad instituida (que también, porque los derechos no han dejado de ser derechos de libertad), sino por organizaciones o individuos que intentan socavar con extorsión, violencia y sangre la democracia.

En los regímenes democráticos se debe tener clara conciencia de que, si bien el terrorismo, actualmente planetario, es un fenómeno que subvierte el orden éti-

${ }^{88}$ ROSENFELD, M.: «¿Es apropiada la ponderación judicial en la lucha contra el terrorismo? Contrastando tiempos normales, emergencias y tiempos de tensión», Real Instituto Elcano de Estudios Internacionales y Estratégicos, Área: Terrorismo Internacional, ARI, n. ${ }^{\circ}$ 109, Madrid, 2005.

89 ACKERMAN, B.: La Costituzione di emergenza. Come salvaguardare libertà e diritti civili di fronte al pericolo del terrorismo, edic. ital., Meltemi, Roma, 2005, pp. 38 ss. 
co y jurídico de los valores, la réplica de los poderes públicos, todo lo contundente que fuere menester, no puede desconocer dichos valores y debe respetar los principios de que se nutre la democracia. Por lo que interesa a este trabajo y en apretada síntesis, dichos principios pueden desglosarse en las siguientes consideraciones puntuales:

\section{1) Respeto y defensa del pluralismo político}

A la clásica pregunta de si debe haber libertad para los enemigos de la libertad la democracia debe dar una respuesta afirmativa, para de inmediato matizarla: libertad para todo menos para poner en peligro la propia democracia que les reconoce su libertad y les garantiza sus derechos. De ahí la legitimidad de la suspensión y disolución tanto de las denominadas asociaciones secretas y paramilitares y de las comúnmente denominadas «asociaciones para delinquir», esto es, las que persigan fines o utilicen medios tipificados como delito (art. 22.5 y 2 respectivamente de la Constitución española), como de los partidos y fuerzas políticas cuyo objetivo, programa y actividad (directa o indirecta, convergente o paralela) sea la destrucción del régimen democrático en cuyos derechos y garantías se amparan para su cometido. Lo contrario constituye un angelismo, buenismo o irenismo suicida que acaso pudiera permitirse un particular, pero no el Estado. Remito a las consideraciones hechas en un epígrafe precedente sobre la ilegalización de Batasuna y la democracia militante.

\section{2) Respeto a la juridicidad estatal}

En secciones anteriores de este estudio se ha puesto de manifiesto suficientemente que si todos, Estado y terroristas, son iguales a la hora de desconocer y quebrantar los derechos humanos, se esfuma la legitimidad del Estado de Derecho para perseguir terroristas y aplicarles la legislación penal. No es que sea puesto en cuestión, de hecho, el monopolio de la fuerza, sino que, más gravemente todavía, se pierde (o mengua considerablemente) la legitimidad en el uso de esa fuerza, lo que constituye de manera indubitable la mejor victoria del terrorismo, porque, en cierto modo, es la vuelta al estado de naturaleza hobbesiano, a la lucha «legítima» (en el problema que analizamos, sedicentemente legítima) de todos contra todos como siniestra consecuencia de la «igualdad natural», con lo que se desemboca en la aspiración igualmente «legítima» (cabe hacer la misma acotación) de victoria de unos sobre otros.

Así, pues, recuperando ideas expuestas a lo largo del presente trabajo y añadiendo otras de más claro signo jurídico-positivo, el respeto a la juridicidad estatal comporta los siguientes principios: 
a) Primacía de la libertad sobre los valores instrumentales, como el orden y la seguridad, en los términos arriba comentados. La primacía de la libertad significa la del ejercicio ordinario de los derechos sobre la situación de emergencia o de tensión, lo que debe de traducirse, según ACKERMAN, en la temporalidad tasada, aun con prórrogas, de dicho estado y, por tanto, en la provisionalidad de las medidas adoptadas ${ }^{90}$.

b) Vigencia y permanente defensa de la seguridad jurídica, la cual requiere a su vez:

b.1) Corrección procedimental tanto en la adopción de medidas cuanto en su aplicación concreta y en su finalización, lo que generalmente comporta la siguiente exigencia.

b.2) Intervención judicial para la adopción de tales medidas y, posteriormente, para el control de su aplicación por parte del Ejecutivo y de sus agentes; en este punto es de recordar que la actitud de los Gobiernos y Parlamentos, con su inclinación favorable al que hemos denominado Derecho penal del enemigo, ha provocado a veces una reacción de los poderes judiciales dirigida a afirmar la vigencia de las garantías constitucionales incluso en la lucha contra el terrorismo internacional, por más que la respuesta nos parezca algo tímida. La conclusión es extraída por BARAK en los siguientes términos: «nuestros jueces de las democracias modernas son llamados para proteger la democracia del terrorismo, o bien de los medios que el Estado pretende utilizar para combatir el terrorismo» ${ }^{91}$.

c) Mantenimiento del normal funcionamiento de las instituciones hasta donde sea posible y compatible con la erradicación del problema que se trata de resolver. Debe procurarse, por tanto, el doble objetivo de la máxima eficacia de las medidas adoptadas con la alteración mínima de dicho funcionamiento. Ahora bien, en un Estado democrático de Derecho, no hay funcionamiento hasta cierto punto normal de las instituciones sin la observancia de otros dos principios, los de legitimidad y responsabilidad.

c.1) Presunción de legitimidad de la actuación de los poderes públicos, y concretamente de las Fuerzas de Seguridad del Estado. En efecto, la dependencia funcionarial de las mismas respecto del poder constituido y su sujeción estricta a los principios democrático, de legalidad, etc., proporcionan hoy una verdadera garantía para tales derechos. Por eso es necesario insistir en que, como autoridad pública y en el ejercicio de la fun-

90 Ibidem, lug. cit.

${ }^{91}$ Citado por IBÁÑEZ LÓPEZ-POZAS, F., y SÁNCHEZ MONTES, M.: «La Sentencia de 26 de julio de 2006 TS en el caso del talibán español», La Ley, n. ${ }^{\circ}$ 6628, Madrid, 12-I-2007, pp. 1 ss. 
ción que le está legalmente conferida, los miembros de las Fuerzas y Cuerpos de Seguridad gozan de presunción de legitimidad ${ }^{92}$. Claro está que es condición indeclinable para ello la absoluta y terminante negación del terrorismo de Estado y de todo tipo de guerra sucia por parte de los poderes públicos; es decir, se impone una severa política de tolerancia cero respecto de eventuales respuestas al terrorismo, a las bandas armadas y al crimen organizado con sus mismas armas.

c.2) Principio de responsabilidad del poder o de los poderes públicos. Así lo enuncia en términos generales el artículo 9.3 y, por lo que concierne al problema que analizamos, así lo concreta el artículo 55.2, ambos de nuestra norma suprema. Pero para hacerlo efectivo es necesario el control parlamentario de la política antiterrorista del Gobierno, como dispone asimismo este último precepto. ACKERMAN entiende que deben exigirse mayorías cualificadas para la declaración parlamentaria de tal situación de emergencia, incluso crecientes para nuevas confirmaciones, y que la Oposición, como contrapeso del incremento de poder del Gobierno, tenga la facultad de vigilancia de la información ${ }^{93}$. Sin embargo, el Tribunal Constitucional español, interpretando el mencionado artículo de nuestro texto supremo, sostiene que lo que éste quiere significar al mencionar el control parlamentario del Gobierno, no es la exigencia de un control específico para cada medida arbitrada por la autoridad gubernativa, sino el ordinario del funcionamiento del Estado. Si lo interpreto bien, es algo así como si considerara que pretender otra cosa en aras del garantismo podría desembocar en una peligrosa ralentización e incluso en una parálisis de la lucha contra el crimen organizado y el terrorismo. Dicho lacónicamente, el principio democrático no debe laborar contra sí mismo.

El principio de responsabilidad del poder se extiende naturalmente a las indemnizaciones debidas a las personas injustamente acusadas en tales ocasiones o que han sufrido merma en sus derechos y garantías constitucionales y legales.

${ }^{2}$ Cfr. TORRES DEL MORAL, A.: «Libertades públicas y Fuerzas de Seguridad», en VV.AA.: Constitución y Seguridad Pública: una reflexión a los veinticinco años (XV Seminario «Duque de Ahumada»), ob. cit., pp. 41-49.

93 ACKERMAN, B.: La Costituzione di emergenza... ob. y lug. cit. 


\section{POST SCRIPTUM}

No está expresamente contenida en el discurso argumental del presente estudio, pero se deriva derechamente del mismo, la reivindicación de consenso entre las fuerzas políticas en la lucha contra las bandas armadas, el crimen organizado y el terrorismo, abandonando posiciones partidistas y todo intento de aprovechar cualquier episodio con fines electoralistas y partidistas. A ello respondió el Pacto Antiterrorista y por las Libertades que sellaron en España los partidos Socialista y Popular, que después ha sufrido desdichadamente algunos altibajos. Pues más vale un error, normalmente enmendable, que el imparable daño que inflige a la democracia la división interesada de las fuerzas políticas en tan crucial cuestión de Estado, uno de los mayores motivos de preocupación política de los españoles.

Title

TERRORISM AND DEMOCRATIC PRINCIPLE

\section{Summary}

1. PRELIMINARY NOTE. 2. VALUES AND AIMS OF THE STATE. 3. THE DIALECTIC SECURITY-FREEDOM. 4. LEGAL INSTRUMENTS TO ACHIEVE SECURITY. 4.1. A brief historical outline. 4.2. A misleading approach to the problem. 4.3. A backward step of the rule of law: towards a criminal law of the enemy. 5. REFERENCE TO SPAIN. 5.1. From the states of emergency towards the standardization of the exception. 5.2. Two periods in the spanish postconstitutional antiterrorism fight. 5.2.1. First period: the coexistence of the criminal law of the enemy with the principle of non intervention and the over-guarantees. 5.2.2. Second period: Suspension and dissolution of political parties. 6. ELECTORAL EFFECTS OF THE SUSPENSION AND DISSOLUTION OF A POLITICAL PARTY. 6.1. The proliferation of substituting candidatures and their difficult illegalization. 6.2. The inclusion in the candidatures of persons condemned for terrorist crimes. 7. FINANCIAL CONSEQUENCES. 7.1. Decrease or loss of the public financing. 7.2. Patrimony liquidation. 8. POLITICAL-INSTITUTIONAL EFFECTS. 8.1. Brief note on some effects which have taken place. 8.2. Preservation of the seats. 8.3. The non-dissolution of the parliamentary group. 
9. IS THE SPANISH DEMOCRACY A SELF-ASSERTIVE DEMOCRACY? 10. THE DEMOCRATIC STATE RULE OF LAW, THE ONLY POSSIBLE ANSWER. 10.1. Terrorism, the State's reply and values. 10.2. Demands of the democratic principles and of the State's rule of law. POST SCRIPTUM.

\section{Resumen}

En la lucha contra el terrorismo, las democracias tienen como límite el principio de juridicidad estatal y el convergente con él y tautológico principio democrático. Pero ello no es óbice alguno para rechazar la simplista y acrítica acusación de ser una democracia militante cuyo concepto peyorativo sostiene la doctrina mayoritaria española. La democracia no es un régimen éticamente neutro y debe ser todo lo fuerte que necesite para defender los valores que propugna.

\section{Abstract}

In combating terrorism, democracies cannot overstep the limits established by the principle of the rule of law and by the tautological principle of democracy, which converges with the first one. This is not counteracted by the reproach of being a self-assertive democracy, regarded as a negative concept by the majority of the Spanish literature. Democracy is not an ethically neutral regime. Democracy must be as strong as required to protect its own values.

\section{Palabras clave}

Valores, fines del Estado, seguridad, libertad, Estado de Derecho, democracia, democracia militante, Derecho penal del enemigo, terrorismo, partidos políticos.

\section{Key words}

Values, State's aims, security, freedom, rule of law, democracy, self-assertive democracy, criminal law of the enemy, terrorism, political parties. 